See discussions, stats, and author profiles for this publication at: https://www.researchgate.net/publication/338676556

Phreatomagmatic vs magmatic eruptive styles in maar- diatremes -a case study at Twin Peaks, Hopi Buttes volcanic field, Navajo Nation, Arizona

Article in Bulletin of Volcanology · January 2020

DOI: 10.1007/500445-020-1365-y

\section{CITATIONS}

0

2 authors:

(1)

Benjamin Latutrie

Institut National de la Recherche Scientifique

13 PUBLICATIONS 12 CITATIONS

SEE PROFILE
READS

58

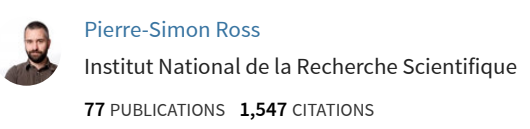

SEE PROFILE

Some of the authors of this publication are also working on these related projects:

Volcanism in the Hopi Buttes volcanic field View project

Uppermost Albian quantitative biochronology: a prerequisite for understanding couplings between major palaeocological and environmental changes View project 


\title{
Phreatomagmatic vs magmatic eruptive styles in maar- diatremes - a case study at Twin Peaks, Hopi Buttes volcanic field, Navajo Nation, Arizona
}

\author{
Benjamin Latutrie*, Pierre-Simon Ross
}

Institut national de la recherche scientifique, Centre Eau Terre Environnement, 490 rue de la Couronne, Québec (QC), G1K 9A9, Canada

* Corresponding author

E-mail addresses: Benjamin.Latutrie@ete.inrs.ca (B. Latutrie), rossps@ete.inrs.ca (P.-S. Ross)

\section{Keywords:}

maar-diatreme, phreatomagmatic, magmatic, fragmentation, lava lakes

\begin{abstract}
The Hopi Buttes volcanic field (HBVF) is located on the Colorado Plateau, northern Arizona. In this Miocene volcanic field, the erosion level increases southward, allowing the study of maar-diatreme volcanoes from top (post-eruptive crater infill and ejecta ring) to bottom (lower diatreme). The Twin Peaks volcanic complex consists mostly of two hills (North Peak and South Peak) with thick lavas at their summits and pyroclastic rocks underneath. In the HBVF, such volcanic remnants have received little scientific attention so far, despite their relative abundance. Our field observations allow us to interpret the North and South Peaks as remnants of two maar-diatreme volcanoes which evolved into lava lakes filling the craters. Within the complex, we distinguish four volcanic units (from unit 1 at the bottom to unit 4 at the top). On the basis of the field description of the deposits and the componentry measurements, we suggest that Unit 1 is phreatomagmatic, Unit 2 is phreato-strombolian (with mixed phreatomagmatic and strombolian characteristics), Unit $3 \mathrm{a}$ is phreato-hawaiian (with mixed phreatomagmatic and hawaiian characteristics), Unit $3 b$ is hawaiian (formed by lava fountains) and Unit 4 consists of lava lakes filling the maar craters. There is therefore a progressive evolution from a purely phreatomagmatic eruptive style, which excavated the craters and diatremes and partly filled them, to magmatic explosive to non-explosive eruptive styles, which filled the maar craters up to the pre-eruptive surface. We discuss traditional criteria used to distinguish phreatomagmatic from magmatic eruptive styles in ultramafic to mafic maar-diatreme volcanoes.
\end{abstract}




\section{Introduction}

Maar-diatreme volcanoes are, after scoria cones, the second most abundant type of volcanoes on continents (Vespermann and Schmincke 2000). They are small, complex, short lived, mainly phreatomagmatic volcanoes that are hazardous for the nearby population (Lorenz 1986, 2007; White and Ross 2011; Valentine and White 2012). Around the world, maar-diatremes are found in active monogenetic volcanic fields, some of which are located near large cities such as Auckland, New Zealand (Németh et al. 2012; Németh and Kereszturi 2015; Nunns and Hochstein 2019) or Goma, Democratic Republic of Congo (Poppe et al. 2016). Maar-diatreme volcanoes comprise a subaerial part composed of an ejecta ring (Self et al. 1980; White 1991; Vazquez and Ort 2006; Valentine et al. 2015) and a maar crater (Lorenz 1973; White 1991; Graettinger 2018). Their subterranean part is composed of an upper typically bedded diatreme (White 1991; Gernon et al. 2013; Delpit et al. 2014), an upper/lower diatreme transition zone (Bélanger and Ross 2018; Latutrie and Ross 2019), a lower nonbedded diatreme (White 1991; Lefebvre et al. 2013, 2016), a root zone (Clement 1982; Lorenz and Kurszlaukis 2007; Haller et al. 2017) and a feeder intrusion (Re et al. 2015, 2016; Muirhead et al. 2016; Le Corvec et al. 2018).

Upper diatreme deposits are bedded pyroclastic deposits emplaced onto the bottom of the syn-eruptive crater. White and Ross (2011) proposed to separate upper diatreme deposits into two types. Type I deposits progressively subside along ring faults during the eruption. Examples of type I deposits are found in the Missouri River Breaks volcanic field of Montana (Delpit et al. 2014). Type II deposits are deposited into deep craters, after an excavation-dominated phase, without strong subsidence. Examples of type II deposits comprise several cases in the Hopi Buttes volcanic field (HBVF) of Arizona, including the upper diatreme infill at Round Butte (Latutrie and Ross 2019). Type II upper diatreme deposits range from phreatomagmatic to magmatic in origin (White and Ross 2011), including in the HBVF. Phreatomagmatic and magmatic vents can be active simultaneously in a maar crater, as observed in 1977 at Ukinrek, Alaska (Kienle et al. 1980; Self et al. 1980;
Büchel and Lorenz 1993; Ort et al. 2018). Another possibility is that the eruptive regime progressively switches from phreatomagmatic to magmatic. If a late magmatic phase of the eruption lasts long enough, the syn-eruptive maar crater could be filled (or over-filled) by a scoria cone (White 1991; Vazquez 1998) or a lava lake (e.g., Martin and Németh 2002; Kereszturi and Németh 2011; Hencz et al. 2017; Latutrie and Ross 2018; Tietz et al. 2018), so that the final landform at the end of the eruption would not necessarily be a maar, even if there is a diatreme under it.

Williams (1936) studied both the HBVF and the older Navajo volcanic field further north. In both fields, post-emplacement erosion has removed variable thicknesses of volcanic rocks and surrounding sedimentary rocks. Williams (1936) observed that volcano remnants in the Navajo volcanic field are typically tuff breccia "shafts" corresponding to pyroclastic rocks from diatremes (e.g., Cathedral Cliff, Bélanger and Ross 2018; Ship Rock, Delaney 1987). In the HBVF, many remnants are 'plug'-dominated, i.e. mostly consisting of thick jointed lavas, and referred to as "Hopi necks" by Williams (1936). Most recent studies in the HBVF did not focus on these 'plug'-dominated remnants, although HBVF workers know about them (e.g., White, pers. commun., 2012; Ort, pers. commun. 2017; authors' observations). Instead, these recent studies documented plumbing systems (Re et al. 2015, 2016; Muirhead et al. 2016), as well as mostly phreatomagmatic pyroclastic rocks from the lower diatreme (Lefebvre et al. 2013, 2016), the upper/lower transition zone (Latutrie and Ross 2019), the upper diatreme (White 1991; Latutrie and Ross 2019), and the ejecta ring (White 1991; Lefebvre et al. 2013; Graettinger and Valentine 2017).

In this paper, we present detailed mapping and interpretation of eruptive processes for a well exposed 'plug'-dominated remnant of the HBVF, the Twin Peaks volcanic complex. We describe four main volcanic units within the complex. Our interpretation is that the diatreme and crater excavation was phreatomagmatic as is typical of maar-diatreme volcanoes, but the crater infilling activity evolved from phreatomagmatic to magmatic. Therefore, Twin Peaks deposits display a 
continuous eruptive sequence from phreatomagmatic to magmatic, making it a great location to document in detail processes involved in this switching of eruptive styles in ultramafic to mafic maar-diatreme volcanoes. We take the opportunity to review and discuss the traditional criteria used to distinguish phreatomagmatic from magmatic eruptive styles in this setting.

\section{Geological setting}

The Miocene HBVF, located in the south central part of the Colorado Plateau, provides excellent exposures of maar-diatreme volcanoes (Fig. 1, Williams 1936; White 1991; Vazquez and Ort 2006; White and Ross 2011). Volcanic remnants are spread in an area of about $2300 \mathrm{~km}^{2}$ (e.g., White 1991; Lefebvre et al. 2013, Latutrie and Ross 2019). Maardiatremes are the main type of monogenetic volcanoes formed in the HBVF during volcanic activity (e.g., Williams 1936; White 1991; Vazquez 1998; Hooten 1999; Lefebvre et al. 2013, 2016; Latutrie and Ross 2019). This is related to the water-rich environments in the Miocene, characterised at the surface by playas and ponds (White 1990) and underground by sub-horizontal aquifers (for current aquifers see Hart et al. 2002). Variable erosion levels in the HBVF allow the study of maar-diatremes from the ejecta ring (White 1991) to the lower diatreme (Lefebvre et al. 2013). The uppermost sedimentary formations in the HBVF region are, from top to bottom, the Miocene Bidahochi Formation, the Lower Jurassic Moenave Formation, and the Upper Triassic Chinle Formation (Fig. 1, Billingsley et al. 2013).

\section{Twin Peaks volcanic complex overview}

Twin Peaks volcanic complex forms the upper part of a $190 \mathrm{~m}$-tall, $\sim 1.3 \mathrm{~km}^{2}$ hill in the southeastern part of the HBVF. The complex consists of two adjacent 'plug'-dominated volcanoes (North and South Peaks, Figs. 3a, 3b) and a small satellite diatreme (Figs. 2, 3c). The lower part of the hill, from $\sim 1700 \mathrm{~m}$ above sea level (a.s.l.) in the south and from $\sim 1720 \mathrm{~m}$ a.s.l. in the north, contains only Upper Triassic (Chinle Formation) to Lower Jurassic (Moenave Formation) sedimentary rocks (Billingsley et al. 2013), often covered by
Quaternary sediments (Fig. 2). The hill rises from a flat plain, the level of which approximates the contact between the Chinle and Moenave Formations (Figs. 1, 2). The lowest exposures of volcanic rocks of the main peaks are at around $1820 \mathrm{~m}$ a.s.l. (on the north flank of the North Peak), and reach $\sim 1890 \mathrm{~m}$ a.s.l. Those of the satellite diatreme are preserved at $\sim 1800 \mathrm{~m}$ a.s.l. within the sedimentary rocks of the Moenave Formation and form a $\sim 20 \mathrm{~m}$ high outcrop (Fig. 3c). The total surface area occupied by volcanic rocks is $36860 \mathrm{~m}^{2}\left(\sim 14320 \mathrm{~m}^{2}\right.$ for the North Peak, $\sim 22210 \mathrm{~m}^{2}$ for the South Peak, and $\sim 330 \mathrm{~m}^{2}$ for the satellite diatreme). The two main peaks display a sequence of pyroclastic rocks capped by thick jointed masses of black lava (Figs. 4, 5, 6). Sedimentary rocks from the Moenave Formation surround the volcanic remnants of each peak, whereas those of the Bidahochi Formation are eroded and not preserved in situ. Pyroclastic deposits in the satellite diatreme are rich in lithic clasts and brown to black juvenile clasts; they are crosscut by numerous basanite dikes. Around the satellite diatreme, we observed tuff and lapilli tuff dikes that are few centimeters to ten centimeters thick (Fig. 3d) with a maximum extension in the south of $\sim 150 \mathrm{~m}$. These dikes are aligned NW-SE and are composed of lithic fragments and brown to black juvenile clasts within a whitish matrix (Fig. 3e). The satellite diatreme and tuff to lapilli tuff dikes are not considered further in this paper.

\section{Methods}

One month of field work was carried out at the Twin Peaks volcanic complex. We first mapped the entire complex, drawing limits of volcanic remnants, sedimentary rocks (Moenave and Chinle Formations, Billingsley et al. 2013) and Quaternary sediments on a geological map, using a satellite image as a background (Fig. 2). Then we mapped volcanic facies on each main peak, but not on the satellite diatreme, which remains undifferentiated (Fig, 3). We defined four volcanic units on the main peaks based on meter-scale observations and lithological descriptions of the rocks. They were named following the stratigraphic order with unit 1 at the bottom and unit 4 at the top. Units 1 to $3 \mathrm{a}$ are pyroclastic and non-welded, unit $3 b$ is 
welded and unit 4 is a lava. Pyroclastic rock nomenclature follows White and Houghton (2006). Welding terms for spatter-bearing rocks are after Wolff and Sumner (2000) and Sumner et al. (2005). Vesicularity terms are taken from Houghton and Wilson (1989). Three subvertical cliffs (two on the North Peak, Fig. 3a and one on the South Peak, Fig. 3b), which provide cross-section-like exposures, were chosen to highlight relationships between the four units. The geology was drawn on highresolution panoramic photographs of the cliffs (Figs. 4, 5, 6).

Componentry was quantified in the field using clast counts (Ross and White 2006) in units 1 and 2. Field clasts counts are analogous to petrographic point counts and yield the volume fraction of components measured. Clast counts were obtained using a $1 \mathrm{~m}^{2}$ net with a $10 \mathrm{~cm}$ mesh allowing us to quantify 100 points. During these measurements we classified only fragments greater or equal to $4 \mathrm{~mm}$ into different componentry bins, and put the rest as undifferentiated matrix (clasts $<4 \mathrm{~mm}$ ) and cement. We did not attempt to distinguish between true juvenile and recycled juvenile fragments during componentry measurements, since this distinction is very tricky. Loaded and cored juvenile clasts (Lefebvre et al. 2013) occur but were not counted separately. No clasts counts were done on unit 3 because these rocks are extremely poor in sedimentary lithic clasts. Note that field clast counts are different from the field line counts mentioned for Round Butte by Latutrie and Ross (2019). We are planning to compare the two methods elsewhere.

A total of 28 samples were taken: 14 are pyroclastic rocks, from unit 1 to 3 , and 14 are non-fragmental rocks: lavas from unit 4 , dikes, and blocks and bombs in unit 1 and unit 2 (Fig. 3). Each sample was sliced with a diamond blade, and the interior examined. This led to a selection of 16 representative samples in which thin sections were made. This includes 11 pyroclastic samples (four from unit 1, four from unit 2 , and three from unit 3 ), and five nonfragmental rocks samples (two lavas in unit 4, one block and one bomb from unit 2 of the South Peak and one dike). All thin sections were petrographically described.
Matrix componentry was quantified by point counting on the thin sections of pyroclastic rocks. We first took images of entire thin sections using a "PowerSlide 5000" slide scanner at an optical resolution of 5000 dpi. Then we point counted the images using the "JMicroVision 1.2.7" free software (Roduit 2007; https://jmicrovision.github.io/; Németh and Kereszturi 2013), with 450 points per thin section and the recursive grid setting.

Finally, geochemical analyses were obtained on all 14 non-fragmental rocks samples, distributed in Unit 3 (two samples of welded spatter), in Unit 4 (four samples of lava), in dikes from the main peaks (three samples), in juvenile blocks and bombs from pyroclastic units (four samples from units 1 and 2) and in a dike crossing the satellite diatreme (one sample). Geochemical methods and results are presented in the Online Resource 1.

\section{Unit descriptions}

\section{Spatial organization of stratigraphic units}

Unit 1 is the oldest and unit 4 is the youngest (Fig. 4). Due to post-volcanic erosion, this forms a concentric pattern in map view (Fig. 3). The north cliff map of the North Peak is the only location displaying the full eruptive sequence (Fig. 4). The other two cliff maps (south faces of both peaks, Figs. 5, 6) show unit 2 to unit 4 .

\section{Unit 1}

Unit 1 forms the bottom $15-20 \mathrm{~m}$ of the north cliff map of the North Peak (Figs. 4, 7) and occurs over $\sim 2 \mathrm{~m}^{2}$ in the South Peak (e.g., sample TPS-7 on Fig. 3b). These pyroclastic rocks are medium brown in color and typically bedded, with sub-horizontal beds or lenses tens of centimeters to several meters thick. The rocks are poorly sorted (visual assessment) and grain size ranges from fine lapilli tuff to tuff breccia. Visual estimates yield $0-30 \%$ blocks and bombs, $40-60 \%$ lapilli, 20-45\% ash and 0$10 \%$ calcite cement (Fig. 7). Beds from unit 1 are juvenile-rich to heterolithic in composition (75-95\% juvenile clasts versus 5-25\% lithics, in the lapilli and block/bomb fractions, see componentry below) but on average they display the highest lithic content of the whole complex.

In the field, juvenile clasts can be grey, black or brown in colour, the latter due to 
palagonite alteration. The brown clasts comprise 10 to $75 \%$ of all juvenile fragments (Fig. 7). Finer-grained beds (fine to medium lapilli tuff) tend to have a higher content in brown juvenile clasts (Figs. 7b, 7d). Independently of colour variations, juvenile clasts in unit 1 are mainly non-vesicular to incipiently vesicular $(0-20 \%$ vesicles $)$ to moderately vesicular (40-60\% vesicles) and rarely highly vesicular (>60\% vesicles). Moderately to highly vesicular clasts (scoria) are rare within beds and lenses of unit 1 (Fig. 7d). Juvenile fragments of all colours display similar shapes, from angular to amoeboid, but are mainly irregular to sub-round (Figs. 7c, 7d, 7e, 7f). Grey and black juvenile are larger on average than the brown ones, reaching block/bomb sizes (Figs. 7a, 7b, 7c). The brown ones range up to coarse lapilli (Figs. 7b, 7d).

Lithics fragments are scattered within the entire unit and derived mainly from the Bidahochi and Moenave Formations. Some lithic clasts originate from the Chinle Formation, perhaps up to $\sim 200-250 \mathrm{~m}$ below their current location. Undifferentiated lithics with an inferred deeper origin are also present in traces. The proportion of lithics within the ash fraction is variable (Figs. 7e, 7f). In thin section, lithic clasts consist of greenish mudstone, greyish siltstone and fine sandstone (Figs. 7e, 7f).

\section{Unit 2}

In the north cliff map of the North Peak, unit 2 sits on top of unit 1 and on both peaks unit 2 is preserved below unit 3. This unit is dark brown, 7-20 $\mathrm{m}$ thick and pyroclastic. These rocks typically form sub-horizontal beds several meters thick composed mostly of poorly sorted medium lapilli tuff to tuff breccia (Figs 4, 5, 6, 8). Visual estimates yield 10-30\% blocks and bombs, 35-60\% lapilli, 15-40\% ash and 0-5\% cement (Figs. 8a, 8b). Some parts of this unit are more thinly bedded, including well sorted medium lapilli tuff beds (Figs. 5, 6). On both peaks, this unit is juvenile-rich with $90-99 \%$ of juvenile clasts against $10-1 \%$ lithic clasts (in the lapilli and block/bomb fractions, see componentry below). Locally, beds with a higher lithic content occur (North Peak, see Figs. 4, 5, 8a; South Peak, see Fig. 8b). In the south cliff map of the South Peak, we observed local peperite (Hooten and Ort 2002) at the contact between unit 2 and a feeder dike for unit 4 (Fig. 6).

In the field, juvenile fragments in unit 2 are mainly grey and black, and occasionally brown (0-15\% of all juvenile clasts). Independently of the color, clasts are mainly irregular, sub-round to amoeboid, rarely subangular, and sometimes elongate like spatter, with a vesicularity ranging from $<10$ to $70 \%$ (Figs. 8c, 8d, 8e). Moderately to highly vesicular clasts (scoria) are present in higher proportion in this unit than in unit 1 (Figs. 8d, 8e) whereas non-vesicular to incipiently vesicular juvenile clasts are less abundant (Figs. $8 \mathrm{c}, 8 \mathrm{~d})$.

Lithic clasts are mainly whitish mudstone, siltstone to fine sandstone, ash to blocks and bombs in size. Some white lithic blocks/lapilli display radial cracks (Fig. 8f), with and a slight rim of alteration, suggesting that they were wet and unconsolidated when they were emplaced (Valentine and van Wyk de Vries 2014). They cooked and desiccated within the pyroclastic deposits and these particular clasts are likely derived from the Bidahochi Formation. Other lithic clasts display angular shapes and could be bleached Moenave Formation clasts (Jm, Fig. 8c). In thin sections or slabs, greenish mudstone from the Bidahochi Formation and reddish to whitish siltstone to fine sandstone from the Moenave Formation are present in these deposits as lapilli- or ash-sized clasts (Tbl, Fig. 8d and Jm, Fig. 8c).

\section{Unit 3}

The $\sim 3-10$ m-thick unit 3 consists of very dark brown to black tuff breccias (Figs. 4, 5, 9). These rocks are extremely juvenile-rich, with only traces of scattered white lithic blocks/lapilli, and are separated in two parts, namely unit $3 \mathrm{a}$ at the bottom and $3 \mathrm{~b}$ at the top. In unit $3 \mathrm{a}$, the spatter clasts are flattened but non-welded and occur in a matrix of fine/medium lapilli tuff, rich in ash (Fig. 9a). In unit $3 b$, the ash matrix is absent, spatter fragments are coarser than in unit $3 \mathrm{a}$ and are welded to strongly welded (Figs. 9b, 9c, 9d), grading locally into metric lenses of clastogenic lava (Fig. 9e). Lenses of clastogenic lavas record their pyroclastic origin by preserving ghosts of scoria, small spatter and non-vesicular 
clasts. Unit $3 \mathrm{~b}$ is also better sorted than unit $3 \mathrm{a}$ with fragments from coarse lapilli to blocks and bombs in size. Rare spindle bombs are present in unit 3b. Spatter fragments in both subunits are generally flat, deformed and highly vesicular (up to $80 \%$ ) with bigger vesicles in the middle (Fig. 9f, Stovall et al. 2011, 2012).

\section{Unit 4}

On each peak, unit 4 is composed of a 50-70 m thick black lava mass (Fig. 10a) that was fed by sub-vertical dikes (Figs. 4, 5, 6, 10b). Unit 4 is entirely jointed from bottom to top. Joints are spaced by $40-50 \mathrm{~cm}$, diffuse to chaotic in the bottom and top parts, and well developed in the middle part (Figs. 4, 5, 6, 10a). In general, within the thick columnar jointed portion, the joint orientation is vertical, but joints become less steep when the lateral margins of unit 4 are approached (Figs. 5, 6).

Samples from unit 4 and from feeder dikes (four samples from unit 4 and three from dikes) are all petrographically similar. These porphyritic rocks are composed of 5-10\%, 0.2$5 \mathrm{~mm}$, slightly to extremely serpentinized olivine; $10-15 \%, \quad 0.2-10 \mathrm{~mm}$, euhedral clinopyroxene; and $0-1 \%$ vesicles (>1 mm, Figs. 10c, 10d). The microcrystalline groundmass contains serpentinized olivine, euhedral clinopyroxene and euhedral oxides (Fig. 10d).

\section{Intrusions}

Dikes that feed unit 4 are mapped on the three cliff maps. These sub-vertical dikes are oriented in a SE-NW direction, are 1-8 $\mathrm{m}$ thick and crosscut pyroclastic units 1 to 3 to feed unit 4 (Figs. 4, 5, 6, 10b). They display amoeboid margins implying an emplacement within unconsolidated pyroclastic sediments of units 1 and 2 (Fig. 10b). The dike that crops out in the south part of the South Peak probably crosscuts the Moenave sedimentary rocks at depth (Figs. 2, 3b), but most dikes at Twin Peaks do not seem to extend into the country rocks at the present level of exposure. We also mapped smaller intrusions that crop out in unit 2 (Figs. $3 \mathrm{a}, 3 \mathrm{~b}, 10 \mathrm{e})$. These are less than a meter thick, crosscut pyroclastic rocks and can be typically followed laterally (sills) or vertically (dikes) over several meters, locally up to $10 \mathrm{~m}$ (Fig. 10e).

\section{Componentry measurements}

\section{Field clast counts}

Field clast counts were carried out on seven sites corresponding to sample names on Fig. 3. They are distributed in unit 1 (three sites on the North Peak) and unit 2 (two sites on the North Peak and two sites on the South Peak) in order to quantify clasts $\geq 4 \mathrm{~mm}$ in long axis, versus 'matrix' (clasts $<4 \mathrm{~mm}$ ) and cement. On average, unit 1 contains $46 \%$ "matrix + cement" whereas unit 2 has $40 \%$ for the South Peak and $30 \%$ for the North Peak (Table 1). In other words, unit 2 is coarser grained than unit 1 . When the proportions of juvenile versus lithic clasts are recalculated to $100 \%$, unit 1 is richer in lithic clasts, with $11 \%$ on average (range from $2 \%$ to $24 \%$ ) against averages of $1 \%$ to $4 \%$ for unit 2 (range from 0-6\%). We also recalculated to $100 \%$ the proportions of the different categories of juvenile clasts and found that on average, unit 1 is the richest in brown juvenile fragments with $20 \%$ (range from 0$34 \%$ ), with other juvenile clasts being grey or black. Brown juvenile clasts are absent from unit 2 of the South Peak and comprise $17 \%$ of one clast count site of unit 2 of the North Peak. Note that most brown juvenile clasts are smaller than $4 \mathrm{~mm}$, so are counted as 'matrix' in the field clast counts.

\section{Petrographic point counts}

For the componentry quantification of the $<4 \mathrm{~mm}$ clasts, we selected eight samples distributed in unit 1 (three samples from the North Peak and one from the South Peak) and unit 2 (two samples from the North Peak and two samples from the South Peak). Sample location is given in Fig. 3. Petrographic point counts show that unit 1 of the North Peak is the richest in interstitial material (Table 2). This represents very fine-grained material that could not be assigned to a specific category based on our image resolution. Unit 2 is on average less rich in interstitial material than unit 1 of the North Peak (Table 2), again showing the poorly sorted nature of unit 1 . One exception is unit 1 from the South Peak, which display the lowest value of interstitial material from all the petrographic point counts, based on only one sample. 
When the average proportion of juvenile versus lithic clasts is recalculated to $100 \%$ in the petrographic point counts, lithics clasts represent $12 \%$ of unit 1 of the North Peak. Unit 2 contains fewer lithic clasts with averages of $7 \%$ on the North Peak and $4 \%$ on the South Peak. We also recalculated to $100 \%$ the proportions of the different categories of juvenile clasts. This highlighted that on average, unit 1 of the North Peak has the highest proportion of brown juvenile clasts with $50 \%$ (range from 9-73\%), whereas unit 2 has only $30 \%$ in the South Peak and $24 \%$ in the North Peak.

The juvenile clasts were counted into four vesicularity categories (Table 2). When recalculated to $100 \%$ juvenile clasts, unit 1 of the North Peak has the smallest abundance of clasts with a vesicularity higher than $40 \%$ (i.e. $17 \%$ clasts with a $40-60 \%$ vesicularity and $9 \%$ clasts with a $>60 \%$ vesicularity). In contrast, unit 2 of the North and South Peaks comprises $34 \%$ and $31 \%$ clasts with $40-60 \%$ vesicles and $6 \%$ and $9 \%$ clasts with $>60 \%$ vesicles, respectively. Non-vesicular to incipiently vesicular juvenile clasts are also more abundant within rocks of unit 1 of the North Peak ranging from $35 \%$ to $61 \%$ with an average value of $51 \%$, whereas unit 2 of the North Peak and South Peak has $45 \%$ and $36 \%$ respectively. In other words, juvenile clasts in unit 1 are less vesicular, on average, than those of unit 2 and vesicularity values in unit 1 are approaching the numbers reported by Ross and White (2012) for diatreme-like deposits at Coomb Hills, Antarctica.

Integration of field clast counts and petrographic point counts

Because the field clast counts and the petrographic point counts are similar methods applied at different scales, we integrated them to obtain an overall componentry estimate (Table 3). The "matrix + cement" value of the field clast counts represents the proportion of material to be accounted for using the petrographic point counts. On average, unit 1 is the richest in interstitial material with an average value of $21 \%$ whereas unit 2 has only low values (10\% for the South Peak and 7\% for the North Peak). Average values of juvenile versus lithic clasts recalculated to $100 \%$ highlight that unit 1 of the North Peak is richer in lithics $(12-25 \%)$ than unit 2 of the North and South Peaks (5\% and 1-3\%, respectively). Considering only juvenile clasts recalculated to $100 \%$, brown juvenile fragments have the highest abundance in unit 1 with 4-33\%. These values do not reach $75 \%$ because we did not analyse the site richer in brown juvenile clasts with the two methods. Thanks to this integration we show that unit 2 of the South Peak contains about $10 \%$ of brown juvenile clasts instead of $0 \%$ as observed in field clast counts. Juvenile clasts are more abundant than lithics in all pyroclastic units. Finally, average values of the unit 2 of the North and South Peaks are extremely similar for all total juvenile and total lithic categories (Table 3).

\section{Origin of Twin Peaks volcanic rocks}

\section{Volcano type}

The top of both peaks approximately corresponds to the pre-eruptive surface, based on measured elevations and regional sedimentary stratigraphy. The lowest volcanic exposures are $70 \mathrm{~m}$ lower, so the pyroclastic and jointed lavas exposed on the two peaks were emplaced 0 to $70 \mathrm{~m}$ below the pre-eruptive surface (Fig. 1). The volcanic rocks are surrounded by sedimentary country rocks, with steep to gently dipping contacts, indicating a funnel shape. Given these shapes for the volcanic rocks and the regional context of the HBVF (White 1991, Lefebvre et al. 2013, 2016, Latutrie and Ross 2019), our interpretation is that the two main peaks and the satellite diatreme each represent the remnant of a maardiatreme volcano. More specifically, for the two main peaks, the exposed pyroclastic and jointed lavas were deposited in coalesced maar craters, with eruptive styles ranging from phreatomagmatic to effusive and correspond to a Type II upper diatreme infill according to White and Ross (2011).

\section{Provenance of lithic clasts}

Units 1 and 2 contain 12-25\% and 1-5\% lithics, respectively (Table 3). Lithic clasts with recognizable provenances are derived mainly from the Bidahochi and Moenave Formations. This shows that excavation of country rocks during the eruption was largely constrained to the first $\sim 170$ m below the pre-eruptive surface 
(Fig. 1). Some lithics have a deeper origin (probably the Chinle Formation), indicating limited excavation at greater depths.

\section{Interpretation of juvenile clasts}

Juvenile fragments in unit 1-3 have the same phenocrysts and almost the same geochemical signature than basanite lava samples of unit 4 , suggesting that they were derived from the same parental magma, although there is evidence for limited compositional variation over time (Online Resource 1). The variation in color in the juvenile fragments from units 1 and 2 is related to their groundmass: altered sideromelane for brown juvenile clasts and tachylite for grey and black juvenile clasts. Formation of sideromelane is related to a high cooling rates whereas tachylite is formed by a slower cooling rate (e.g., Furnes 1975; Stroncik and Schmincke 2002; White and Valentine 2016). In the literature, sideromelane fragments are mostly associated with water/magma interaction (White and Ross 2011; Lefebvre et al. 2013, 2016; Bélanger and Ross 2018; Latutrie and Ross 2019) but sideromelane fragments can also form in magmatic explosions (e.g., Stromboli, Cannata et al. 2014 and Mt Etna, Taddeucci et al. 2004; Andronico et al. 2009). Amoeboid and spatter fragments were deposited while still hot.

\section{Unit 1}

Unit 1 pyroclastic rocks are poorly sorted, bedded, fine lapilli tuffs to tuff breccias that display a high proportion of interstitial (optically irresolvable) material (Table 3, average value of $21 \%$ ), probably representing fine ash. The thickness of the multiple subhorizontal beds and lenses of unit 1 are centimeters to meters and vary from one facies to another (e.g., fLT-Ph to TB-Ph on Fig. 4). Rocks are variable in componentry but are generally rich in lithic clasts (5-25\%, Table 3). This indicates abundant country rock fragmentation during the eruption. Several types of juvenile clasts occur in unit 1 , but brown ones are more abundant than in other units. Finally, juvenile clasts have a variable vesicularity, ranging from $0 \%$ to over $60 \%$, but about half are non-vesicular to incipiently vesicular (Table 2), showing that fragmentation occurred independently of magma vesiculation.
All of this, plus the occurrence of this unit in a crater excavated into country rocks, points to phreatomagmatic activity for unit 1 (Valentine et al. 2017). Unit 1 is typical of phreatomagmatic deposits within upper diatremes in the HBVF and elsewhere (Lorenz 1986; White 1991; White and Ross 2011; Lefebvre et al. 2013; Valentine et al. 2017; Latutrie and Ross 2019).

The bedded sequence of unit 1 is composed by multiple beds or lenses that were formed by numerous subterranean explosions located below the current levels of exposure in the diatreme structure. The strongest explosions were able to reach the surface (syn-eruptive crater floor) and form plumes in and above the crater (White and Ross 2011; Ross et al. 2013; Valentine et al. 2014). Coarse grained thick beds and lenses are inferred to have formed from fallback into the crater or from pyroclastic density currents (PDCs, White and Ross 2011; Ross et al. 2013; Latutrie and Ross 2019). Bedded deposits of unit 1 were likely emplaced where they are today, since no strong evidence of subsidence, like saucer shaped beds or faults, was found. This means that at some point during the eruption, the crater floor of the North Peak eruptive centre was deeper than the bottom part of unit 1 in the north cliff of the North Peak, i.e. $\sim 70 \mathrm{~m}$ (Fig. 4).

\section{Unit 2}

Unit 2 is mainly formed by thick sub-horizontal beds of poorly sorted coarse lapilli tuff to tuff breccia (Figs. 4, 5) and sometimes displays thinly bedded packets of better sorted medium lapilli tuff (Fig. 5). Interstitial material, brown juvenile lapilli and non-vesicular to incipiently vesicular clasts are less abundant than in unit 1 (Tables 2, 3). Unit 2 can be followed all around the two peaks, including a specific lithic-rich bed in the North Peak (Figs. 4, 5). Rocks from unit 2 are richer in moderately to highly vesicular clasts (scoria) than unit 1 . Clasts like scoria are more typically formed in hawaiian and strombolian activity (Sumner et al. 2005; Cannata et al. 2014; Gurioli et al. 2014; Taddeucci et al. 2015). Yet unit 2 still has some phreatomagmatic characteristics such as a significant proportion of non-vesicular to incipiently vesicular juvenile clasts, brown juvenile clasts, and some beds with high lithic 
contents. The mix of strombolian and phreatomagmatic features within unit 2 can be called informally "phreato-strombolian" and can be explained in different ways. Two vents, one phreatomagmatic and one strombolian, may have been simultaneously active, as seen during the eruption of East Maar at Ukinrek (e.g., Self et al. 1980; Büchel and Lorenz 1993; Ort et al. 2018). These vents could have been located in the same crater, or in different craters (North Peak versus South Peak). An intriguing alternative is that a single vent, with an eruptive style transitional between strombolian and phreatomagmatic, produced unit 2 in each crater. The details of how this would work are unclear, but may involve sloppy strombolian bursts resulting from an entrainment of water saturated host sediments, peperite or pyroclastic deposits along with the magma, as proposed by Valentine and van Wyk de Vries (2014). Or else, ingestion of slurry or liquid water within the strombolian conduit at depth could trigger weakly explosive water-magma interactions, as experimentally obtained by Sonder et al. (2018). The shift from purely phreatomagmatic activity for unit 1 to a more transitional one in unit 2 can be explained either by an increased magma flux or by a decreased water supply. The thick beds in unit 2 were mainly emplaced by fallback in the crater (White and Ross 2011; Latutrie and Ross 2019).

The small intrusive dikes and sills found in unit 2 formed after the end of the deposition of the pyroclastic deposits of unit 2 (Fig. 3). These intrusions display amoeboid edges implying an emplacement within unconsolidated pyroclastic deposits (Fig. 10e). We consider that these small intrusions derive from the feeder dike that nourished the following units 3 and 4. The feeder dike was able to form fingers that crosscut unit 2 and probably unit 1 deeper in the diatreme.

\section{Unit 3}

Unit 3 is composed by non-welded spatter (unit 3a, Fig. 9a) overlain by welded spatter (unit 3b, Figs. 9b, 9c). These deposits are juvenile-rich ( $<1 \%$ lithics) and mainly composed of flattened spatter clasts (bombs and coarse lapilli). The spatter clasts display a gradient in the vesicle size with larger vesicles in the core and small vesicles in the edges (Fig. 9f).
Unit 3a: non-welded spatter

Unit $3 \mathrm{a}$ is composed of non-welded spatter within a pyroclastic matrix (fine/medium lapilli tuff), which is not typical of classic lava fountain deposits (Wolff and Sumner 2000; Andronico et al. 2008; Taddeucci et al. 2015). The pyroclastic matrix and the spatter were emplaced simultaneously, so unit $3 \mathrm{a}$ is a "phreato-hawaiian" deposit (informal term). To form this mixed deposit, two vents might have been active at the same time: one phreatomagmatic (or phreato-strombolian), and one hawaiian (lava fountain). Water may have been still available for water-magma interactions at the phreatomagmatic or phreatostrombolian vent, while a lava fountain started at the other vent (Kósik et al. 2016). Again, these two vents could have been located in the same crater, or in separate craters. The accumulation rate of the spatter was probably low to accommodate mixing of the pyroclastic matrix and non-welded spatter. More speculatively, unit 3 a could have formed from a single "phreato-hawaiian" vent. Slurry or liquid water may have been entrained within the hawaiian conduit, resulting in recycling of existing pyroclastic debris and/or additional water-related magma fragmentation. Or, if there was a steep slope around the vent, pyroclastic deposits could have slid to the lava fountain and have been recycled.

\section{Unit 3b: welded spatter}

Unit $3 b$ is composed of welded spatter deposits and clastogenic lavas typical of lava fountain activity (Head and Wilson 1989; Sumner 1998; Sumner et al. 2005; Andronico et al. 2008). No hint of magma-water interaction is seen in unit 3b. Non-vesicular clasts found in clastogenic lava could come from the recycling of nonvesicular clasts from unit 1 or unit 2 .

\section{Unit 4}

Unit 4, at the top of the two peaks, is a thick lava with well-developed columnar joints in some portions. The thick feeder dikes (1 to $9 \mathrm{~m}$ wide) that crosscut the three underlying pyroclastic units (Figs. 4, 5, 6, 10b) are not typical of the HBVF, where most dikes are 0.4-1 m wide (Re et al. 2015, 2016; Muirhead et al. 2016). A large flux of basanite magma widened the feeder 
dikes within the diatremes, and the top of the dikes may have further widened due to the weight of the lava accumulation in the crater. Ongoing lava fountaining in the maar craters, with a high rate of spatter agglutination, could have nourished clastogenic lavas (Head and Wilson 1989; Sumner et al. 2005; Carracedo Sánchez et al. 2012) and formed a lava lake (Tazieff 1994; Lavine and Aalto 2002). Or else the magma within the dike was unable to fragment and the activity became effusive. Eventually the coalesced maar craters filled up with lava up to the pre-eruptive surface and may have overflowed. The lava lakes then cooled slowly over decades (Wright and Peck 1978; Cas and Wright 1988; Tazzieff 1994), during which joints formed perpendicularly to the cooling surface (DeGraff and Aydin 1987). Joints patterns on both peaks are typical of lava lakes formed within a crater (Tietz et al. 2018).

\section{Simultaneously active craters?}

There is no evidence for any long pauses during the formation of the Twin Peaks volcanic complex. It seems likely that the formation of the two main peaks and the satellite diatreme are part of the same overall eruptive activity, along the same NW-SE feeder dike, although whether the craters were all active simultaneously is not clear. A first possibility is that activity migrated laterally over time to form separate volcanoes, like happened at Ukinrek (e.g., Self et al. 1980; Büchel and Lorenz 1993, Ort et al. 2018). This implies that the North and South Peaks had the same evolution in eruptive styles, but each formed completely separately, in succession. Because the two main craters (North and South Peaks) are close in space, and might have eventually coalesced, this seems unlikely. Also, the geochemical differences actually observed, for example the $\mathrm{MgO}$ variations, are between units 1-3 versus unit 4, not between the two peaks (Online resource 1), suggesting that the unit 4 magma was the same at the two peaks, and was erupted after units 1-3 were emplaced at each peak.

So we hypothesize that the complex generally evolved from pyroclastic activity (units 1-3 in both peaks) to effusive and more $\mathrm{Mg}$-rich magma (unit 4 in both peaks). However, the detailed timing of emplacement for units 1 to 3 in each of the main craters remains unclear. It is possible that a first crater was active, forming the succession from phreatomagmatic to magmatic pyroclastic deposits (units 1 to 3 ) before the feeder dike migrated and formed the second crater in exactly the same way. Alternatively, there could have been a simultaneous activity of the two main peaks evolving more or less in the same way. Or their evolution may have been similar, but not perfectly synchronous, so that one crater could still have been in the phreatomagmatic stage while the other had turned strombolian or phreato-strombolian. This would help to explain the 'mixed' or 'transitional' deposits in units 2 and $3 \mathrm{a}$, by cross-contamination.

\section{Twin Peaks evolution model}

Since the North Peak and the South Peak show the same overall evolution, for simplicity our model shows only the activity of the North Peak (Fig. 11). The model has six steps and is presented as a cross-section through the interior of the peak (see section A-A' in Fig. 2). Features that are below the current erosion level are inferred from the literature and from other examples of maar-diatreme volcanoes in the HBVF.

\section{Onset of activity}

A basanite dike rose through the sedimentary rocks of the Colorado Plateau and interacted explosively with groundwater (Fig. 11a). Maardiatreme volcanoes can be fed by plugs, sills or sheets ( Re et al. 2015, 2016; Muirhead et al. 2016; Le Corvec et al. 2018) but because pyroclastic rocks of unit 1 to unit 3 are cross-cut by thick feeder dikes (Figs, 4, 5, 6, 10b) we chose to draw a dike as the feeder of the Twin Peaks volcanic complex. Initially, the dike is inferred to have a thickness close to the typical thickness of dikes in the HBVF ( 0.4-1 m thick, Re et al. 2015, 2016; Muirhead et al. 2016). Phreatomagmatic explosions that occurred close to the pre-eruptive surface were able to excavate a small maar crater (Fig. 11a, Valentine et al. 2014). Pyroclastic surges and fallout started to form the ejecta ring while phreatomagmatic activity deepened the maar crater and progressively filled it with pyroclastic deposits of the proto-diatreme.

\section{Phreatomagmatic activity}


With ongoing phreatomagmatic activity, country rocks were excavated and a relatively deep diatreme formed (Fig. 11b), with a crater that was likely at least $100 \mathrm{~m}$ deep. Bedded pyroclastic rocks of unit 1 are a typical example of phreatomagmatic upper diatreme bedded deposits in the HBVF, and were deposited at the bottom of this maar crater. In Fig. 11b, deposits below unit 1 are hypothetical and based on the model proposed by Latutrie and Ross (2019) for the nearby Round Butte diatreme. There, the diatreme is composed at the top by a wellbedded upper diatreme and at the bottom by a lower non-bedded diatreme, either homogeneous or displaying vertical structures called "invasive columns" (Fig. 11b). In between the upper and lower diatreme is a transition zone. At this stage, the feeder dike was still thin and nourished fingers within the lower diatreme deposits (and perhaps the upper diatreme as well) to allow phreatomagmatic explosions (Fig. 12a).

\section{Phreato-strombolian activity}

Unit 2 displays both phreatomagmatic and magmatic (strombolian) characteristics and its formation is discussed in detail above. To simplify the figure, we choose to draw one "phreato-strombolian" vent, but separate strombolian and phreatomagmatic vents could have been active. The change in eruptive regime, relative to that which prevailed earlier, could have resulted from an increased magma flux and/or a decreased water supply. At the end of this stage the feeder dike reached a shallower depth and thickened or widened, to feed the lava fountain and the lava lake (Fig. 12b).

\section{Lava fountain activity}

Unit $3 \mathrm{a}$ is transitional between phreatomagmatic and lava fountain deposits (see details on its origin above), whereas unit $3 \mathrm{~b}$ consists of typical hawaiian lava fountain products. To simplify the figure, we choose to draw a typical lava fountain for the whole unit 3 (Fig. 11d). At the same time, the feeder dike formed fingers that cross-cut pyroclastic deposits of unit 1 and 2 .

\section{Lava lake filling the crater}

The final stage of the eruption formed a lava lake (unit 4) which likely finished filling up the maar crater (Fig. 11e). The lava lake may have overflowed to feed lava flows on the preeruptive surface. Concurrently, within the diatreme, the feeder dike probably continued to thicken and form more fingers. These fingers did not have water/magma interactions because the pyroclastic deposits of the diatreme had dried up. After the eruptive activity ended, the lava lake cooled slowly and joints started to form.

\section{Post-eruptive erosion}

After the end of the eruptive activity, erosion removed part of the surrounding country rocks (Fig. 11f). Sedimentary rocks from the Bidahochi Formation were completely eroded whereas those from the Moenave Formation are still present and form the steep to gentle slopes around the volcanic remnants. However, the thick jointed basanite masses of unit 4 protected the pyroclastic deposits of units 1 to 3 .

\section{Phreatomagmatic vs magmatic eruptive styles in ultramafic to mafic maar-diatreme settings}

White and Valentine (2016) summarized the difficulties to find unambiguous criteria to distinguish phreatomagmatic vs magmatic fragmentation in pyroclastic deposits. They reviewed traditional criteria such as grain size, juvenile clast vesicularity and morphology, the nature of the volcanic glass, welding and agglutination, particle aggregation, and lithic contents. When all magma compositions (ultramafic to felsic) and eruption styles, including subaqueous ones, are taken into account, the traditional criteria tend to be ambiguous or have exceptions.

Fortunately, the phreatomagmatic versus magmatic distinction problem is much simpler if restricted to subaerial ultramafic to mafic monogenetic volcanoes, and maardiatreme ones in particular (White and Ross 2011; Ross et al. 2018). Within this very restricted realm, the traditional criteria reviewed by White and Valentine (2016) still mostly work (Table 4). We present mainly field to macroscopic criteria, that can be applied to both historical eruptions and ancient deposits such as those at Twin Peaks, which are altered and cemented. This prevents examination of the 
3D shapes and surface features of ash particles, which are therefore not included in Table 4.

As shown here for Twin Peaks and in previous studies elsewhere, phreatomagmatic bedded deposits in upper diatremes and maar ejecta rings are usually paler in color, more poorly sorted, poorly to strongly cemented, richer in ash, and richer in lithic clasts, compared to the rare magmatic pyroclastic deposits found in the same settings (Moore et al. 1966: Houghton and Schmincke 1989; White 1991; Houghton et al. 1996; Zimanowski et al. 1997; White and Ross 2011; Latutrie and Ross 2018; Ross et al. 2018). These bedded deposits display millimetric to metric sub-horizontal to lensoid beds formed by PDCs, surges, fallback (upper diatreme), fallout (ejecta ring), and ballistic ejection (e.g., White and Ross 2011; Bélanger and Ross 2018; Latutrie and Ross 2019). Cross-bedding, dunes and bomb sags can be found in those deposits (e.g., Fisher and Waters 1970; Crowe and Fisher 1973; Ross et al. 2011; Delpit et al. 2014). Phreatomagmatic juvenile clasts are angular to irregular (and amoeboid) in shape and can display brittle to fluidal surface features (Walker and Croasdale 1971; Heiken and Wohletz 1985; Ross et al. 2018). Loaded and cored bombs are frequent in phreatomagmatic eruptions (Sottili et al. 2010; Lefebvre et al. 2013). They also exhibit a large range of vesicularities from non-vesicular to rarely highly vesicular (Houghton and Wilson 1989; White and Ross 2011; Ross et al. 2018).

On the other hand, strombolian deposits in maar-diatreme settings are darker in color, better sorted, generally poorly cemented, poorer in ash, and poorer in lithic clasts (Self et al. 1974; Houghton and Schmincke 1989; Houghton et al. 1996; Ross et al. 2011, 2018; Saucedo et al. 2017). Fallout from the small plume and ballistic ejection are the main processes responsible for the formation of strombolian beds (Houghton and Schmincke 1989; Houghton et al. 1996; Ross et al. 2011, 2018; Cannata et al. 2014). Beds are usually sub-horizontal, structureless to diffusely stratified (Houghton and Schmincke 1989; Houghton et al. 1996; Ross et al. 2011). The juvenile clasts are more vesicular, with a smaller range of vesicularities and they are more irregular in shape, with their shapes controlled by vesicles (Walker and Croasdale
1971; Heiken and Wohletz 1985; Houghton and Wilson 1989; Cannata et al. 2014). Hawaiian deposits in maar-diatreme volcanoes are dark brown to black, diffusely bedded, non-welded to welded, better sorted than phreatomagmatic deposits, poor in ash and lithic clasts (Sumner et al. 2005; Andronico et al. 2008, 2009). Hawaiian juvenile clasts are mainly scoria and spatter, moderately vesicular to extremely vesicular (Stovall et al. 2011, 2012; Gurioli et al. 2014). These juvenile clasts are amoeboid fluidal clasts that flatten on landing and can agglutinate (Head and Wilson 1989; Sumner 1998; Andronico et al. 2008, 2009).

The texture of the groundmass of juvenile fragments seems to be an ambiguous criterion. Although the classic view is that sideromelane forms in contact with water whereas tachylite does not (e.g., White 1996; White and Ross 2011; Latutrie and Ross 2019), there are now too many exceptions to keep this as a strong rule. For example, strombolian to hawaiian activity at Stromboli (Cannata et al. 2014) and Mt Etna (Taddeucci el al. 2004; Andronico et al. 2009) have formed sideromelane. Conversely, tachylitic juvenile clasts have been reported from phreatomagmatic deposits in maar-diatreme settings (e.g., Ross et al. 2011, Lefebvre et al. 2013; Bélanger et al. 2019; Latutrie and Ross 2019).

\section{Conclusions}

This study documents for the first time one of the 'plug'-dominated volcanic remnants which are common in the HBVF (Williams 1936). The Twin Peaks volcanic complex is an excellent site to discuss:

1. the nature of these 'plug'dominated volcanic remnants;

2. the processes that produce a change in the eruptive regime from phreatomagmatic to magmatic;

3. the criteria used to distinguish phreatomagmatic from magmatic eruptive styles in ultramafic to mafic maar-diatremes.

The two main peaks (North and South) and the satellite diatreme that compose the Twin Peaks volcanic complex are preserved within Moenave Formation sedimentary rocks. The 
North and South Peaks are composed by pyroclastic rocks (unit 1 to 3 ) overlain by jointed lava (unit 4) and these volcanic rocks have gentle to steep contacts with the sedimentary rocks implying a funnel shape structure. Twin Peaks volcanic complex was probably formed by the simultaneous eruption of three maar-diatremes volcanoes along a southeast-northwest direction (Fig. 12a). All pyroclastic rocks and lavas exposed on the two main peaks were deposited within maar craters. These volcanoes were probably active for days to weeks (Self et al. 1980; Büchel and Lorenz 1993) whereas the small satellite diatreme was probably active during a few days at most.

In this paper we documented an eruptive sequence that starts with purely phreatomagmatic deposits (unit 1) overlain by phreato-strombolian deposits (unit 2), by phreato-hawaiian deposits (unit 3a), and by hawaiian lava fountain deposits (unit 3b). It ended with lava lakes filling the maar craters (unit 4, Fig. 12b). This sequence found in the North and South Peaks resulted from the progressive increase of the magma flux and/or the decrease of the water supply or availability. We reviewed the traditional criteria to distinguish phreatomagmatic from magmatic explosive eruptive styles in ultramafic to mafic maar-diatreme settings and conclude that most of those criteria are still helpful. However, groundmass textures (tachylite vs sideromelane) in juvenile fragments appear to be an ambiguous criteria and more work seems needed to investigate these criteria carefully.

\section{Acknowledgements}

Twin Peaks was first visited by PSR during a field trip with James D.L. White, Greg A. Valentine, and Nathalie Lefebvre. These researchers have influenced our ideas through discussions and their papers. We thank Greg A. Valentine for reading the draft of the manuscript and Romain Jattiot for helping us during the field work in the steep slopes. We thank the Morris family for allowing us to work at Twin Peaks. Any persons wishing to conduct geological investigations on the Navajo Nation must first apply for, and receive, a permit from the Navajo Nation Minerals Department, P.O. Box 1910, Window Rock, Arizona 86515, USA, telephone 1-928-871-6587. We thank Alison H. Graettinger, Karoly Németh and editor Jacopo Taddeucci for their constructive reviews.

\section{References}

Andronico D, Cristaldi A, Scollo S (2008) The 4-5 September 2007 lava fountain at south-east crater of Mt Etna, Italy. J Volcanol Geotherm Res 173:325-328

Andronico D, Cristaldi A, Del Carlo P, Taddeucci J (2009) Shifting styles of basaltic explosive activity during the 2002-03 eruption of Mt. Etna, Italy. J Volcanol Geotherm Res 180:110-122

Bélanger C, Ross P-S (2018) Origin of nonbedded pyroclastic rocks in the Cathedral Cliff diatreme, Navajo volcanic field, New Mexico. Bull Volcanol 80:article 61

Bélanger C, White JDL, Fierstein J (2019) Pyroclast Characteristics of the Ubehebe Crater Cluster, Death Valley, California IUGG Centenial. Montreal, Quebec, Canada

Billingsley GH, Block D, Hiza-Redsteer M (2013) Geologic map of the Winslow 30'× 60' quadrangle, Coconino and Navajo Counties, northern Arizona. US Geol Surv Scientific Investigations, Map 3247, scale 1:50 000

Büchel G, Lorenz V (1993) Syn-and post-eruptive mechanism of the Alaskan Ukinrek maars in 1977. In: Paleolimnology of European Maar Lakes. Springer, pp 15-60

Cannata CB, De Rosa R, Donato P, Taddeucci J (2014) Ash features from ordinary activity at Stromboli volcano. Int J Geosci 5:1361 
Carracedo Sánchez M, Sarrionandia F, Arostegui J, Eguiluz L, Gil Ibarguchi JI (2012) The transition of spatter to lava-like body in lava fountain deposits: features and examples from the Cabezo Segura volcano (Calatrava, Spain). J Volcanol Geotherm Res 227:1-14

Cas RAF, Wright JV (1988) Volcanic successions modern and ancient: A geological approach to processes, products and successions. Springer

Clement CR (1982) A comparative geological study of some major kimberlite pipes in the Northern Cape and Orange Free State. PhD thesis, University of Cape Town

Crowe BM, Fisher RV (1973) Sedimentary structures in base-surge deposits with special reference to cross-bedding, Ubehebe Craters, Death Valley, California. Geol Soc Am Bull 84:663-682

DeGraff JM, Aydin A (1987) Surface morphology of columnar joints and its significance to mechanics and direction of joint growth. Geol Soc Am Bull 99:605-617

Delaney PT (1987) Ship Rock, New Mexico: the vent of a violent volcanic eruption. Geological society of America Centennial Field Guide, Rocky Mountain Section 2:411-415

Delpit S, Ross P-S, Hearn BC (2014) Deep-bedded ultramafic diatremes in the Missouri River Breaks volcanic field, Montana, USA: $1 \mathrm{~km}$ of syn-eruptive subsidence. Bull Volcanol 76:article 832

Fisher RV, Waters AC (1970) Base surge bed forms in maar volcanoes. Am J Sci 268:157-180

Furnes H (1975) Experimental palagonitization of basaltic glasses of varied composition. Contrib Mineral Petrol 50:105-113

Gernon TM, Upton BGJ, Hincks TK (2013) Eruptive history of an alkali basaltic diatreme from Elie Ness, Fife, Scotland. Bull Volcanol 75:article 704

Graettinger AH (2018) Trends in maar crater size and shape using the global Maar Volcano Location and Shape (MaarVLS) database. J Volcanol Geotherm Res 357:1-13

Graettinger AH, Valentine GA (2017) Evidence for the relative depths and energies of phreatomagmatic explosions recorded in tephra rings. Bull Volcanol 79:article 88

Gurioli L, Colo' L, Bollasina AJ, Harris AJL, Whittington A, Ripepe M (2014) Dynamics of Strombolian explosions: Inferences from field and laboratory studies of erupted bombs from Stromboli volcano. J Geophys Res: Solid Earth 119(1):319-345

Haller MJ, Ross P-S, White JDL, Lefebvre NS (2017) Overview of the Cerro Chivo volcanic field (CCVF), Chubut province, Argentina: Basalt sheets, root zones, diatrenes and 'plug'. In: XX Congreso Geologico Argentino. San Miguel de Tucumàn, Argentina, 8 p.

Hart RJ, Ward JJ, Bills DJ, Flynn ME (2002) Generalized hydrogeology and ground-water budget for the $\mathrm{C}$ aquifer, Little Colorado River Basin and parts of the Verde and Salt River Basins, Arizona and New Mexico. US Geol Surv Water-Resources Investigations Report: 02-4026

Head JW, Wilson L (1989) Basaltic pyroclastic eruptions: influence of gas-release patterns and volume fluxes on fountain structure, and the formation of cinder cones, spatter cones, rootless flows, lava ponds and lava flows. J Volcanol Geotherm Res 37:261-271

Heiken G (1972) Morphology and petrography of volcanic ashes. Geol Soc Am Bull 83:1961-1988

Heiken G, Wohletz K (1985) Volcanic ash. University Presses of California, Chicago, Harvard \& MIT

Hencz M, Karátson D, Németh K, Biró T (2017) A Badacsony freatomagmás piroklasztit-sorozata: következtetések a monogenetikus bazaltvulkáni müködés folyamataira és formáira. Földtani Közlöny 147:297-310 [in Hungarian with English abstract] 
Hooten JA (1999) Phreatomagmatic diatremes of the western Hopi Buttes volcanic field, Navajo Nation, Arizona. MSc thesis, University of Northern Arizona, USA

Hooten JA, Ort MH (2002) Peperite as a record of early-stage phreatomagmatic fragmentation processes: an example from the Hopi Buttes volcanic field, Navajo Nation, Arizona, USA. J Volcanol Geotherm Res 114:95-106

Houghton BF, Schmincke H-U (1989) Rothenberg scoria cone, East Eifel: a complex Strombolian and phreatomagmatic volcano. Bull Volcanol 52:28-48

Houghton BF, Wilson CJN (1989) A vesicularity index for pyroclastic deposits. Bull Volcanol 51:451462

Houghton BF, Wilson CJN, Rosenberg MD, Smith IEM, Parker RJ (1996) Mixed deposits of complex magmatic and phreatomagmatic volcanism: an example from Crater Hill, Auckland, New Zealand. Bull Volcanol 58:59-66

Kereszturi G, Németh K (2011) Shallow-seated controls on the evolution of the Upper Pliocene Kopaszhegy nested monogenetic volcanic chain in the Western Pannonian Basin (Hungary). Geologica Carpathica 62:535-546

Kienle J, Kyle PR, Self S, Motyka RJ, Lorenz V (1980) Ukinrek Maars, Alaska, I. April 1977 eruption sequence, petrology and tectonic setting. J Volcanol Geotherm Res 7:11-37

Kósik S, Németh K, Kereszturi G, Procter JN, Zellmer GF, Geshi N (2016) Phreatomagmatic and waterinfluenced Strombolian eruptions of a small-volume parasitic cone complex on the southern ringplain of Mt. Ruapehu, New Zealand: facies architecture and eruption mechanisms of the Ohakune Volcanic Complex controlled by an unstable fissure eruption. J Volcanol Geotherm Res 327:99-115

Latutrie B, Ross P-S (2018) Lava lakes filling phreatomagmatic craters at Twin Peaks, Hopi Buttes volcanic field, Navajo Nation, Arizona. Seventh International Maar Conference, Olot, Spain

Latutrie B, Ross P-S (2019) Transition zone between the upper diatreme and lower diatreme: origin and significance at Round Butte, Hopi Buttes volcanic field, Navajo Nation, Arizona. Bull Volcanol 81 :article 26

Lavine A, Aalto KR (2002) Morphology of a crater-filling lava lake margin, The Peninsula tuff cone, Tule Lake National Wildlife Refuge, California: implications for formation of peperite textures. J Volcanol Geotherm Res 114:147-163

Le Corvec N, Muirhead JD, White JDL (2018) Shallow magma diversions during explosive diatremeforming eruptions. Nat Commun 9:1459

Lefebvre NS (2013) Volcanology of maar-diatreme volcanic vent complexes, Hopi Buttes Volcanic Field, Navajo Nation, Arizona, USA. PhD thesis, University of Otago, New Zealand

Lefebvre NS, White JDL, Kjarsgaard BA (2013) Unbedded diatreme deposits reveal maar-diatremeforming eruptive processes: Standing Rocks West, Hopi Buttes, Navajo Nation, USA. Bull Volcanol 75:1-17

Lefebvre NS, White JDL, Kjarsgaard BA (2016) Arrested diatreme development: Standing Rocks East, Hopi Buttes, Navajo Nation, USA. J Volcanol Geotherm Res 310:186-208

Lorenz V (1973) On the formation of maars. Bull Volcanol 37:183-204

Lorenz V (1974) Vesiculated tuffs and associated features. Sedimentology 21:273-291 
Lorenz V (1986) On the growth of maars and diatremes and its relevance to the formation of tuff rings. Bull Volcanol 48:265-274

Lorenz V (2007) Syn-and posteruptive hazards of maar-diatreme volcanoes. J Volcanol Geotherm Res 159:285-312

Lorenz V, Kurszlaukis S (2007) Root zone processes in the phreatomagmatic pipe emplacement model and consequences for the evolution of maar-diatreme volcanoes. J Volcanol Geotherm Res 159:4-32

Martin U, Nemeth K (2002) Interaction between lava lakes and pyroclastic sequences in phreatomagmatic volcanoes: Halàp and Badacsony, Western Hungary. Geologica Carpathica 53, CBGA Conference.

Moore JG, Nakamura K, Alcaraz A (1966) The 1965 eruption of Taal volcano. Science 151:955-960

Muirhead JD, Van Eaton AR, Re G, White JDL, Ort MH (2016) Monogenetic volcanoes fed by interconnected dikes and sills in the Hopi Buttes volcanic field, Navajo Nation, USA. Bull Volcanol 78:1-16

Németh K, Kereszturi G (2013) On the variety of Mio-Pleistocene root zones of monogenetic volcanoes of the Pannonian Basin. In Buechner J, Rapprich V, Tietz O (eds) Basalt 2013 - Cenozoic Magmatism in Central Europe, Abstract Book \& Excursion Guides.

Németh K, Kereszturi G (2015) Monogenetic volcanism: personal views and discussion. Int J Earth Sci 104:2131-2146

Németh K, Cronin SJ, Smith IEM, Flores J (2012) Amplified hazard of small-volume monogenetic eruptions due to environmental controls, Orakei Basin, Auckland Volcanic Field, New Zealand. Bull Volcanol 74:2121-2137

Nunns AG, Hochstein MP (2019) Geophysical constraints on the structure and formation of Onepoto, Orakei, Pupuke and Tank Farm maar volcanoes, Auckland Volcanic Field. New Zealand J Geol Geophys 62:1-16

Ollier CD (1967) Maars their characteristics, varieties and definition. Bull Volcanol 31:45-73

Ort MH, Lefebvre NS, Neal CA, McConnell VS, Wohletz KH (2018) Linking the Ukinrek 1977 maareruption observations to the tephra deposits: New insights into maar depositional processes. $\mathrm{J}$ Volcanol Geotherm Res 360:36-60

Poppe S, Smets B, Fontijn K, Rukeza MB, Migabo ADMF, Milungu AK, Namogo DB, Kervyn F, Kervyn M (2016) Holocene phreatomagmatic eruptions alongside the densely populated northern shoreline of Lake Kivu, East African Rift: timing and hazard implications. Bull Volcanol 78:article 82

Re G, White JDL, Ort MH (2015) Dikes, sills, and stress-regime evolution during emplacement of the Jagged Rocks complex, Hopi Buttes Volcanic field, Navajo Nation, USA. J Volcanol Geotherm Res 295:65-79

Re G, White JDL, Muirhead JD, Ort MH (2016) Subterranean fragmentation of magma during conduit initiation and evolution in the shallow plumbing system of the small-volume Jagged Rocks volcanoes (Hopi Buttes Volcanic Field, Arizona, USA). Bull Volcanol 78:article 55

Roduit N (2007) JMicroVision : un logiciel d'analyse d'images pétrographiques polyvalent. PhD thesis, Université de Genève. 
Ross P-S, White JDL (2006) Debris jets in continental phreatomagmatic volcanoes: a field study of their subterranean deposits in the Coombs Hills vent complex, Antarctica. J Volcanol Geotherm Res 149:62-84

Ross P-S, White JDL (2012) Quantification of vesicle characteristics in some diatreme-filling deposits, and the explosivity levels of magma-water interactions within diatremes. J Volcanol Geotherm Res 245:55-67

Ross P-S, Delpit S, Haller MJ, Németh K, Corbella H (2011) Influence of the substrate on maar-diatreme volcanoes - an example of a mixed setting from the Pali Aike volcanic field, Argentina. J Volcanol Geotherm Res 201:253-271

Ross P-S, White JDL, Valentine GA, Taddeucci J, Sonder I, Andrews RG (2013) Experimental birth of a maar-diatreme volcano. J Volcanol Geotherm Res 260:1-12

Ross P-S, White JDL, Valentine GA, Latutrie B (2018) Distinguishing magmatic from phreatomagmatic pyroclastic deposits at prehistoric mafic maar volcanoes. In: Cities on volcanoes. Naples, Italy

Saucedo R, Macías JL, Ocampo-Díaz YZE, Gómez-Villa W, Rivera-Olguín E, Castro-Govea R, Sánchez-Núñez JM, Layer PW, Hernández JR, Carrasco-Núñez G (2017) Mixed magmaticphreatomagmatic explosions during the formation of the Joya Honda maar, San Luis Potosí, Mexico. Geol Soc Special Pub 446:255-279

Self S, Sparks RSJ, Booth B, Walker GPL (1974) The 1973 Heimaey strombolian scoria deposit, Iceland. Geol Mag 111:539-548

Self S, Kienle J, Huot J-P (1980) Ukinrek Maars, Alaska, II. Deposits and formation of the 1977 craters. J Volcanol Geotherm Res 7:39-65

Sohn YK (1996) Hydrovolcanic processes forming basaltic tuff rings and cones on Cheju Island, Korea. Geol Soc Am Bull 108:1199-1211

Sonder I, Harp AG, Graettinger AH, Moitra P, Valentine GA, Büttner R, Zimanowski B (2018) MeterScale Experiments on Magma-Water Interaction. J Geophys Res: Solid Earth 123:10,597510,615

Sottili G, Taddeucci J, Palladino D (2010) Constraints on magma-wall rock thermal interaction during explosive eruptions from textural analysis of cored bombs. Journal of Volcanology and Geothermal Research 192:27-34

Stovall WK, Houghton BF, Gonnermann H, Fagents SA, Swanson DA (2011) Eruption dynamics of Hawaiian-style fountains: the case study of episode 1 of the Kîlauea Iki 1959 eruption. Bull Volcanol 73:511-529

Stovall WK, Houghton BF, Hammer JE, Fagents SA, Swanson DA (2012) Vesiculation of high fountaining Hawaiian eruptions: episodes 15 and 16 of 1959 Kīlauea Iki. Bull Volcanol 74:441 455

Stroncik NA, Schmincke H-U (2002) Palagonite-a review. Int J Earth Sci 91:680-697

Sumner JM (1998) Formation of clastogenic lava flows during fissure eruption and scoria cone collapse: the 1986 eruption of Izu-Oshima Volcano, eastern Japan. Bull Volcanol 60:195-212

Sumner JM, Blake S, Matela RJ, Wolff JA (2005) Spatter. J Volcanol Geotherm Res 142:49-65

Taddeucci J, Pompilio M, Scarlato P (2004) Conduit processes during the July-August 2001 explosive activity of Mt. Etna (Italy): inferences from glass chemistry and crystal size distribution of ash particles. J Volcanol Geotherm Res 137:33-54 
Taddeucci J, Alatorre-Ibarguengoitia MA, Palladino DM, Scarlato P, Camaldo C (2015) High-speed imaging of Strombolian eruptions: Gas-pyroclast dynamics in initial volcanic jets. Geophys Res Lett 42:6253-6260

Tazieff H (1994) Permanent lava lakes: observed facts and induced mechanisms. J Volcanol Geotherm Res 63:3-11

Tietz O, Buchner J, Lapp M, Scholle T (2018) The Stolpen Volcano in the Lausitz Volcanic Field (East Germany)-volcanological, petrographic and geochemical investigations at the type locality of basalt. J Geosci 63:299-315

Valentine GA, White JDL (2012) Revised conceptual model for maar-diatremes: Subsurface processes, energetics, and eruptive products. Geology 40:1111-1114

Valentine GA, van Wyk de Vries B (2014) Unconventional maar diatreme and associated intrusions in the soft sediment-hosted Mardoux structure (Gergovie, France). Bull Volcanol 76:807

Valentine GA, Graettinger AH, Sonder I (2014) Explosion depths for phreatomagmatic eruptions. Geophys Res Lett 41:3045-3051

Valentine GA, Sottili G, Palladino DM, Taddeucci J (2015) Tephra ring interpretation in light of evolving maar-diatreme concepts: Stracciacappa maar (central Italy). J Volcanol Geotherm Res 308:1929

Valentine GA, White JDL, Ross P-S, Graettinger AH, Sonder I (2017) Updates to concepts on phreatomagmatic maar-diatremes and their pyroclastic deposits. Frontiers Earth Sci 5:68

Vazquez JA (1998) Maar volcanism in the Wood Chop Mesa area, Hopi Buttes volcanic field, Navajo Nation, Arizona. MSc thesis, University of Northern Arizona, USA

Vazquez JA, Ort MH (2006) Facies variation of eruption units produced by the passage of single pyroclastic surge currents, Hopi Buttes volcanic field, USA. J Volcanol Geotherm Res 154:222236

Vespermann D, Schmincke H-U (2000) Scoria cones and tuff rings. In: Sigurdsson H, Houghton B, McNutt S, Rymer H, Stix J (eds) Encyclopedia of volcanoes. Academic, San Diego, pp 683694

Walker GPL, Croasdale R (1971) Characteristics of some basaltic pyroclastics. Bull Volcanol 35:303317

White JDL (1990) Depositional architecture of a maar-pitted playa: sedimentation in the Hopi Buttes volcanic field, northeastern Arizona, USA. Sediment Geol 67:55-84

White JDL (1991) Maar-diatreme phreatomagmatism at Hopi Buttes, Navajo Nation (Arizona), USA. Bull Volcanol 53:239-258

White JDL (1996) Pre-emergent construction of a lacustrine basaltic volcano, Pahvant Butte, Utah (USA). Bull Volcanol 58:249-262

White JDL, Houghton BF (2006) Primary volcaniclastic rocks. Geology 34:677-680

White JDL, Ross P-S (2011) Maar-diatreme volcanoes: a review. J Volcanol Geotherm Res 201:1-29

White JDL, Valentine GA (2016) Magmatic versus phreatomagmatic fragmentation: absence of evidence is not evidence of absence. Geosphere 12:1478-1488

Williams H (1936) Pliocene volcanoes of the Navajo-Hopi country. Geol Soc Am Bull 47:111-172 
Wolff JA, Sumner JM (2000) Lava fountains and their products. In: Sigurdsson H, Houghton B, McNutt S, Rymer H, Stix J (eds) Encyclopedia of volcanoes. Academic, San Diego, pp 321-330

Womer MB, Greely R, King JS (1980) The geology of Split Butte-a maar of the south-central Snake River Plain, Idaho. Bull Volcanol 43:453-471

Wright TL, Peck DL (1978) Crystallization and differentiation of the Alae Lava Lake, Hawaii. U.S. Geol Surv Prof Pap 935-C: 1-20p

Zimanowski B, Büttner R, Lorenz V, Häfele HG (1997) Fragmentation of basaltic melt in the course of explosive volcanism. J Geophys Res: Solid Earth 102:803-814

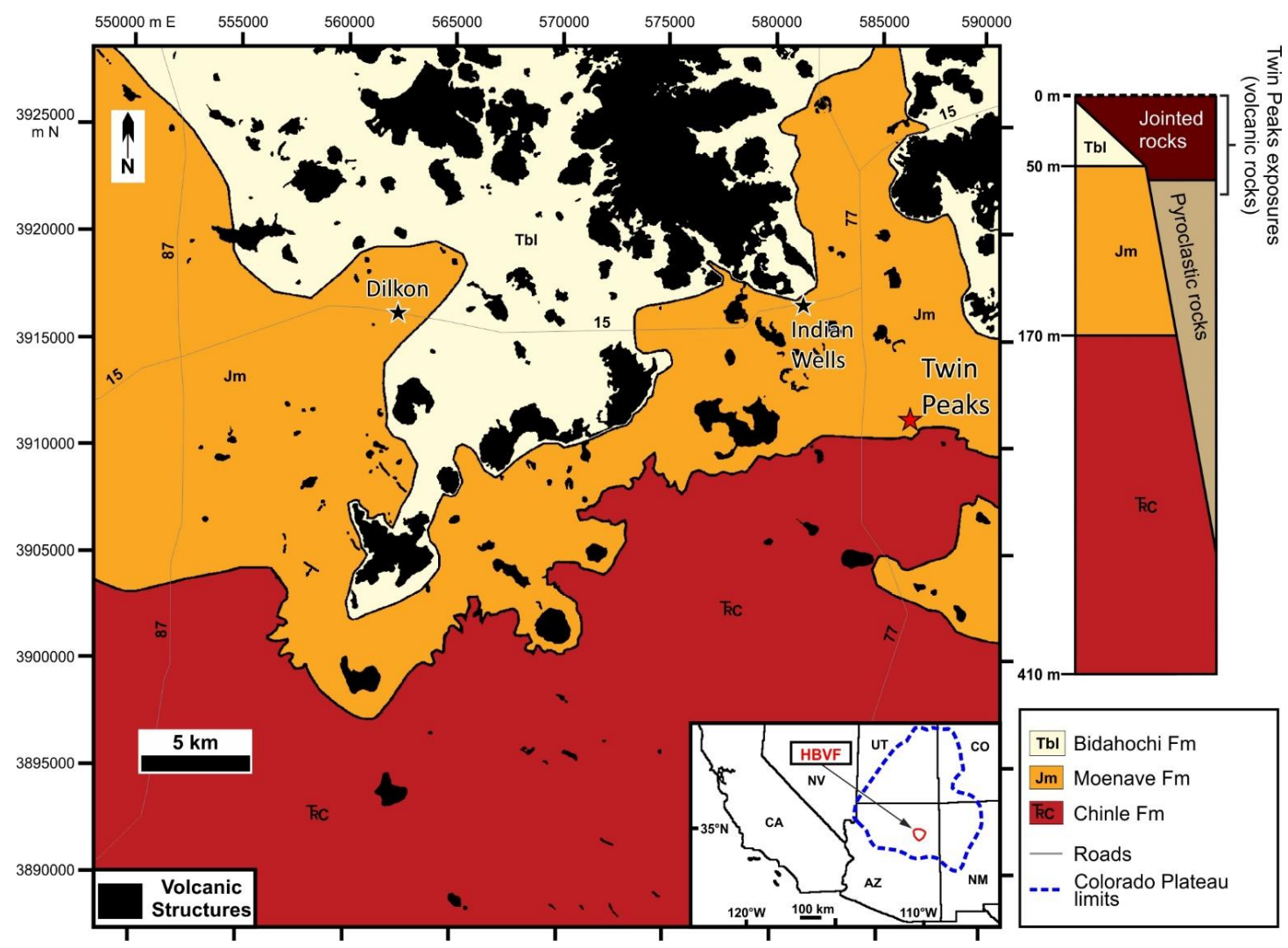

Fig. 1 Geological map of the HBVF showing igneous remnants (black) and the main sedimentary formations. Grid is UTM WGS 84 zone 12S. Inset map locates the HBVF within the Colorado Plateau. Stratigraphic log illustrates the thickness of the main sedimentary formations and the exposure of Twin Peaks volcanic rocks (jointed lava and pyroclastic rocks). Black stars locate the main villages of the area. Modified from Lefebvre (2013). 


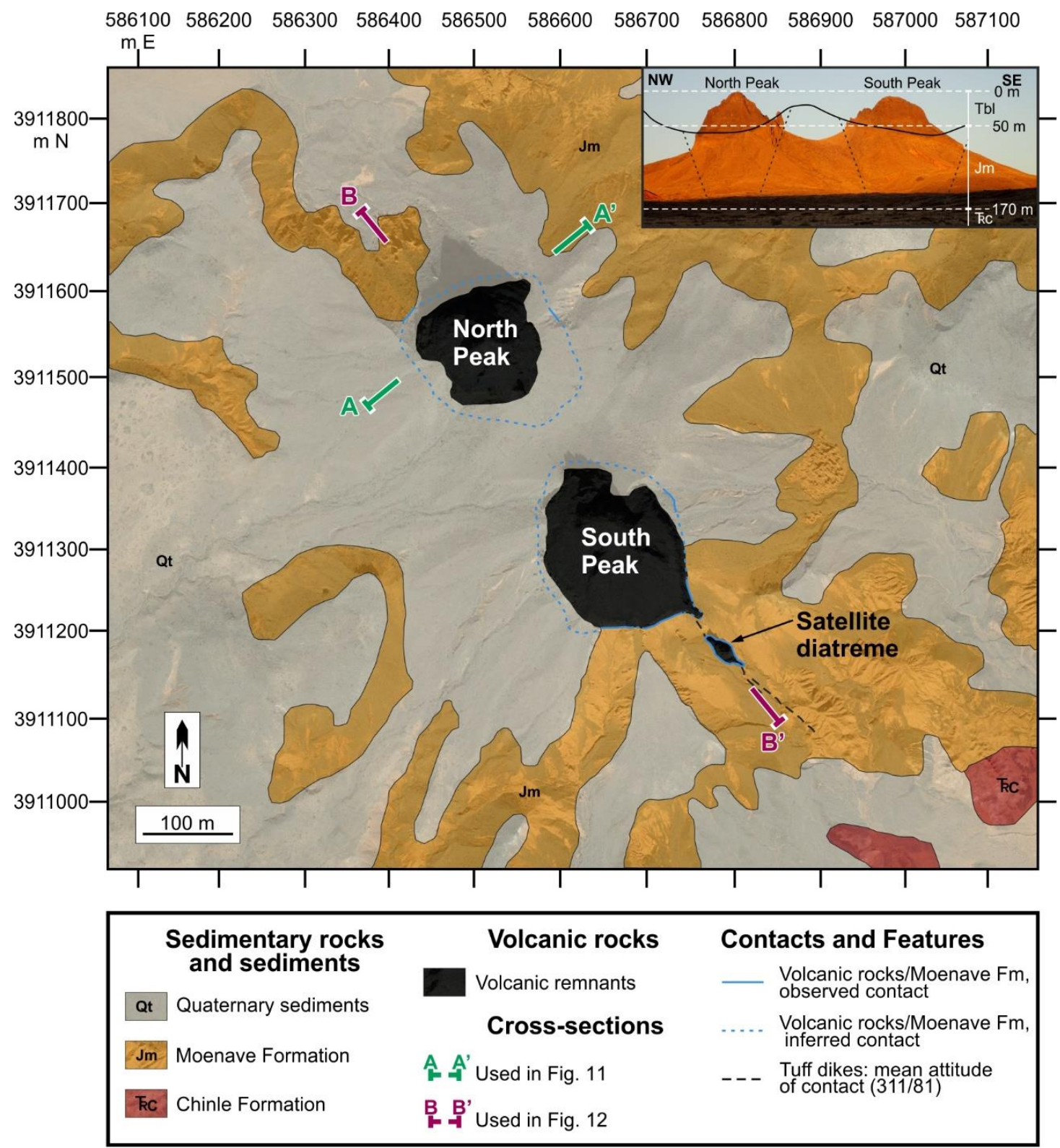

Fig. 2 Geological map of the Twin Peaks volcanic complex showing the two main peaks (North and South) and the satellite diatreme. Grid is UTM WGS 84 zone 12S. Inset photograph show the current morphology of the two main peaks, looking NE. The satellite diatreme is hidden on the other side of the south slope of the South Peak. Dashed line represents the slopes of the inferred diatreme below the two main peaks on the B-B' cross-section whereas the black line corresponds to the crater floors as seen on the photograph. 


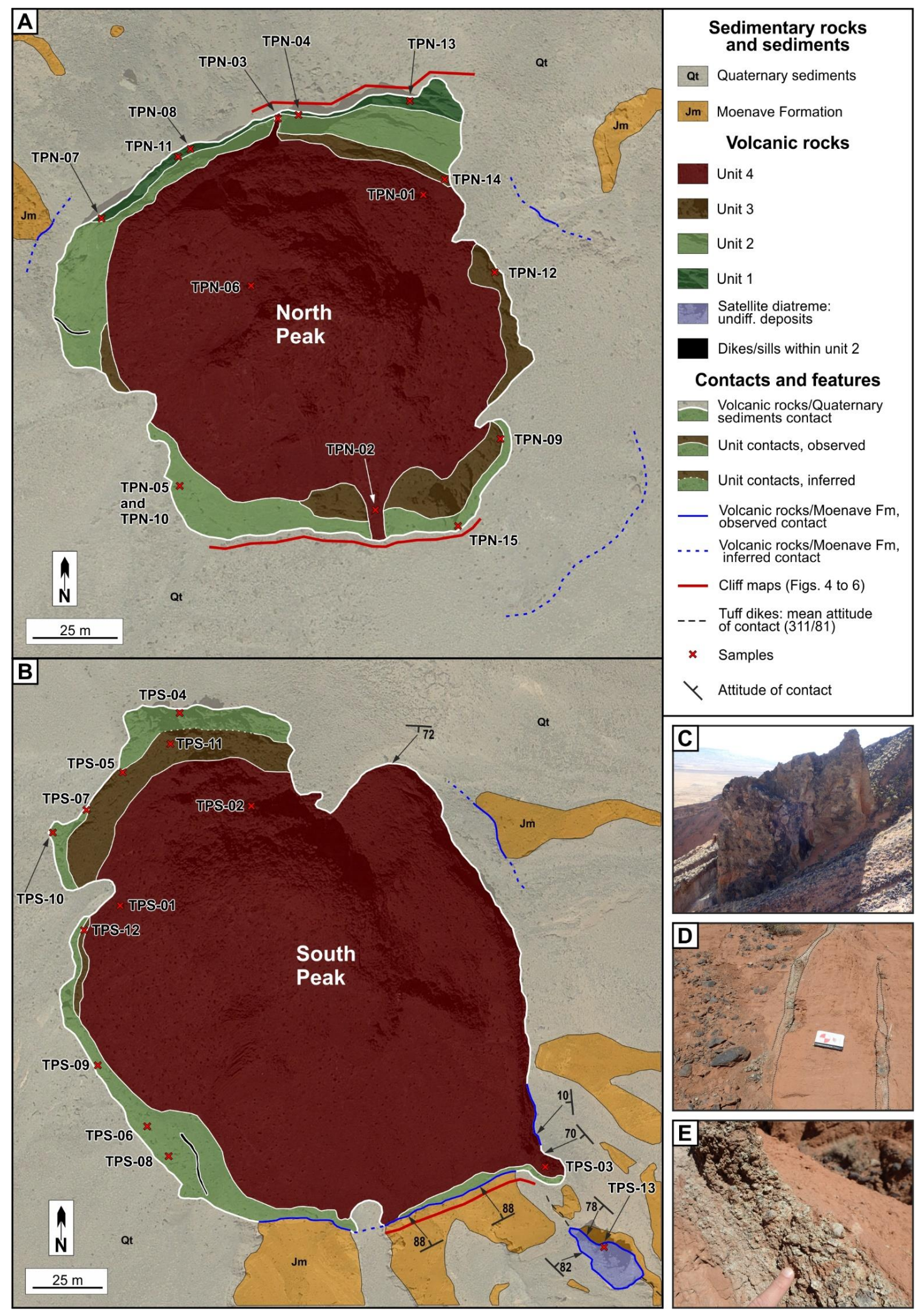

Fig. 3 Detailed geological map of Twin Peaks. A) Zoom on the geology of the North Peak, B) zoom on geology of the South Peak, C) photo showing the vertical extension of the undifferentiated satellite diatreme, D) tuff to lapilli tuff dikes in the south of the satellite diatreme and E) close-up on the componentry of the tuff to lapilli tuff dikes. 


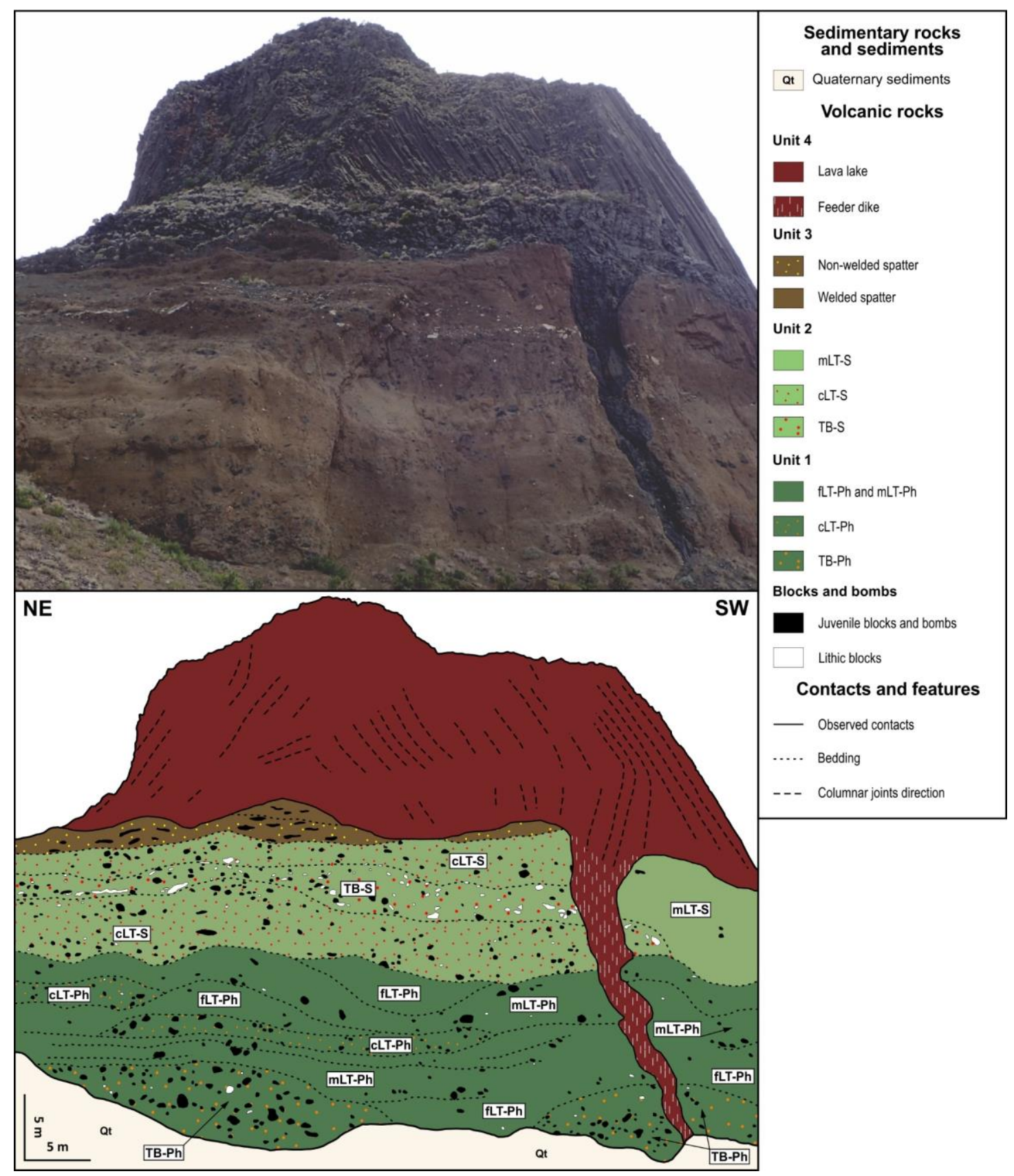

Fig. 4 Geology of the north cliff of the North Peak. fLT-Ph = phreatomagmatic fine lapilli tuff, $\mathrm{mLT}-\mathrm{Ph}$ $=$ phreatomagmatic medium lapilli tuff, $\mathrm{cLT}-\mathrm{Ph}=$ phreatomagmatic coarse lapilli tuff, $\mathrm{TB}-\mathrm{Ph}=$ phreatomagmatic tuff breccia, mLT-S = phreato-strombolian medium lapilli tuff, cLT-S = phreatostrombolian coarse lapilli tuff and TB-S = phreato-strombolian tuff breccia. 


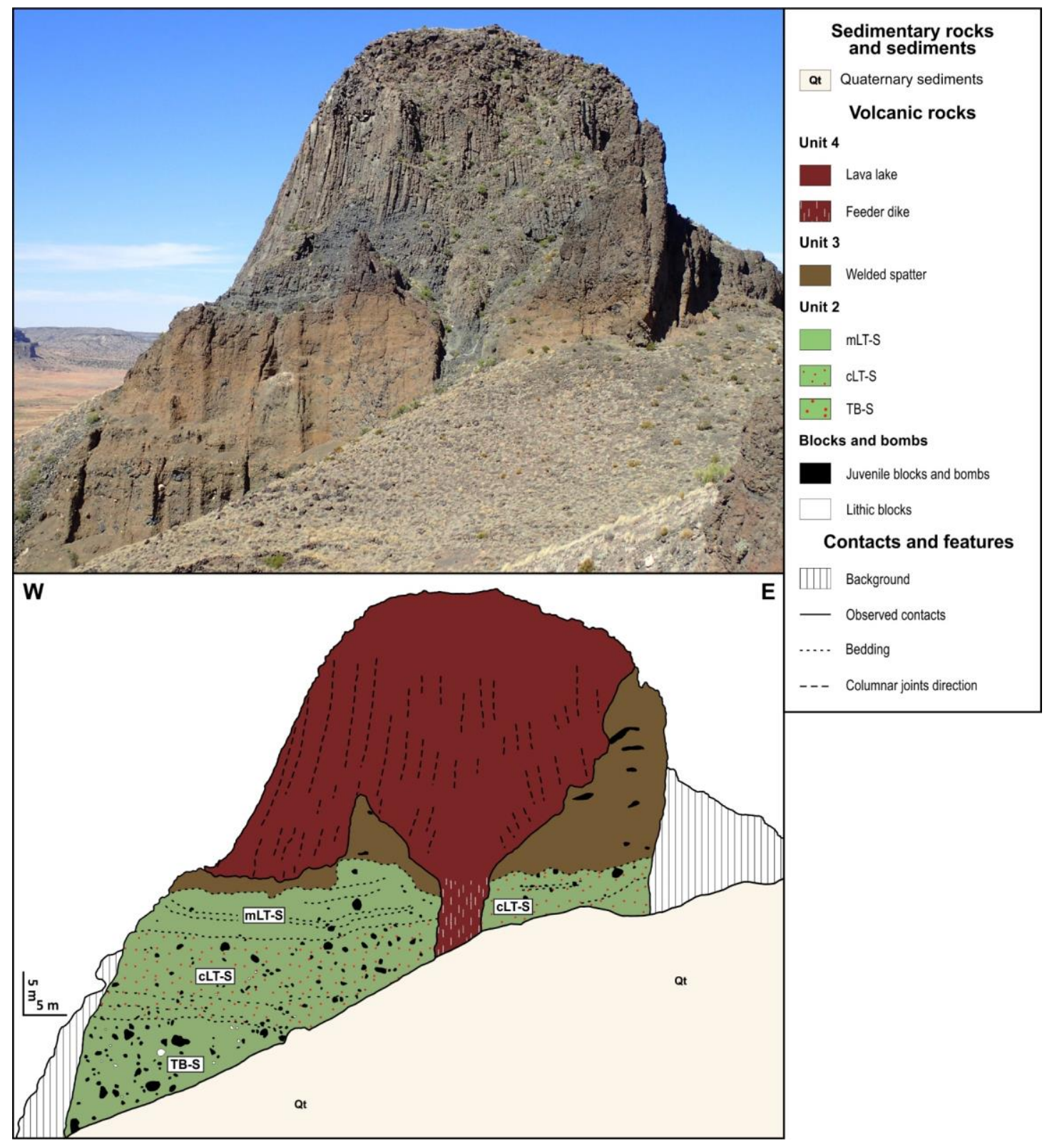

Fig. 5 Geology of the south cliff of the North Peak. mLT-S = phreato-strombolian medium lapilli tuff, cLT-S = phreato-strombolian coarse lapilli tuff and TB-S = phreato-strombolian tuff breccia. 


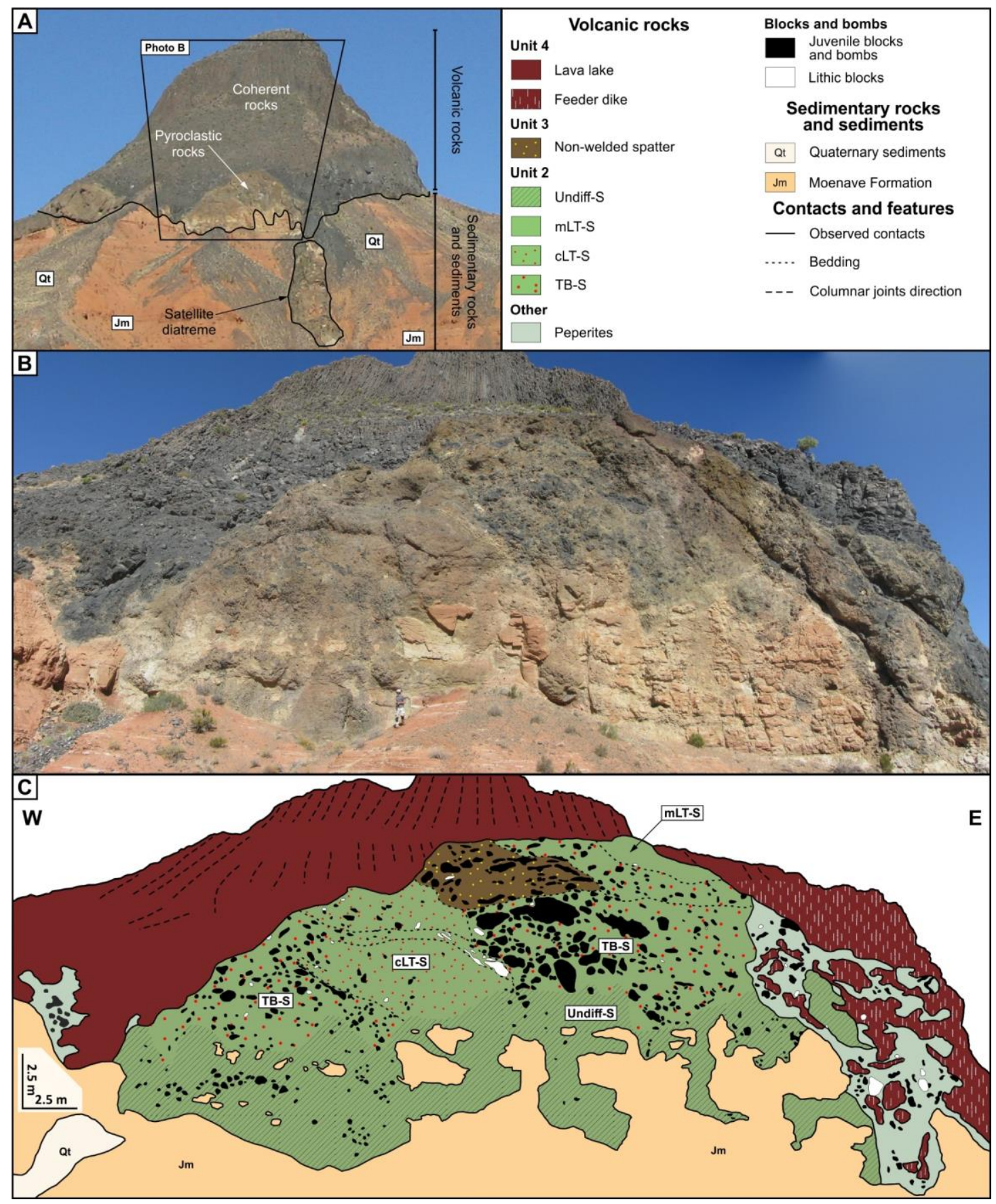

Fig. 6 Geology of the south face of the South Peak. A) General view of the south face of the South Peak showing the perspective distortion of the photograph in B and C, B) Photograph of the south cliff, C) Geological map of the deposits highlighting the architecture of unit 2 to 4 . Undiff-S = phreatostrombolian, undifferentiated, mLT-S = phreato-strombolian medium lapilli tuff, cLT-S = phreatostrombolian coarse lapilli tuff and TB-S = phreato-strombolian tuff breccia. 

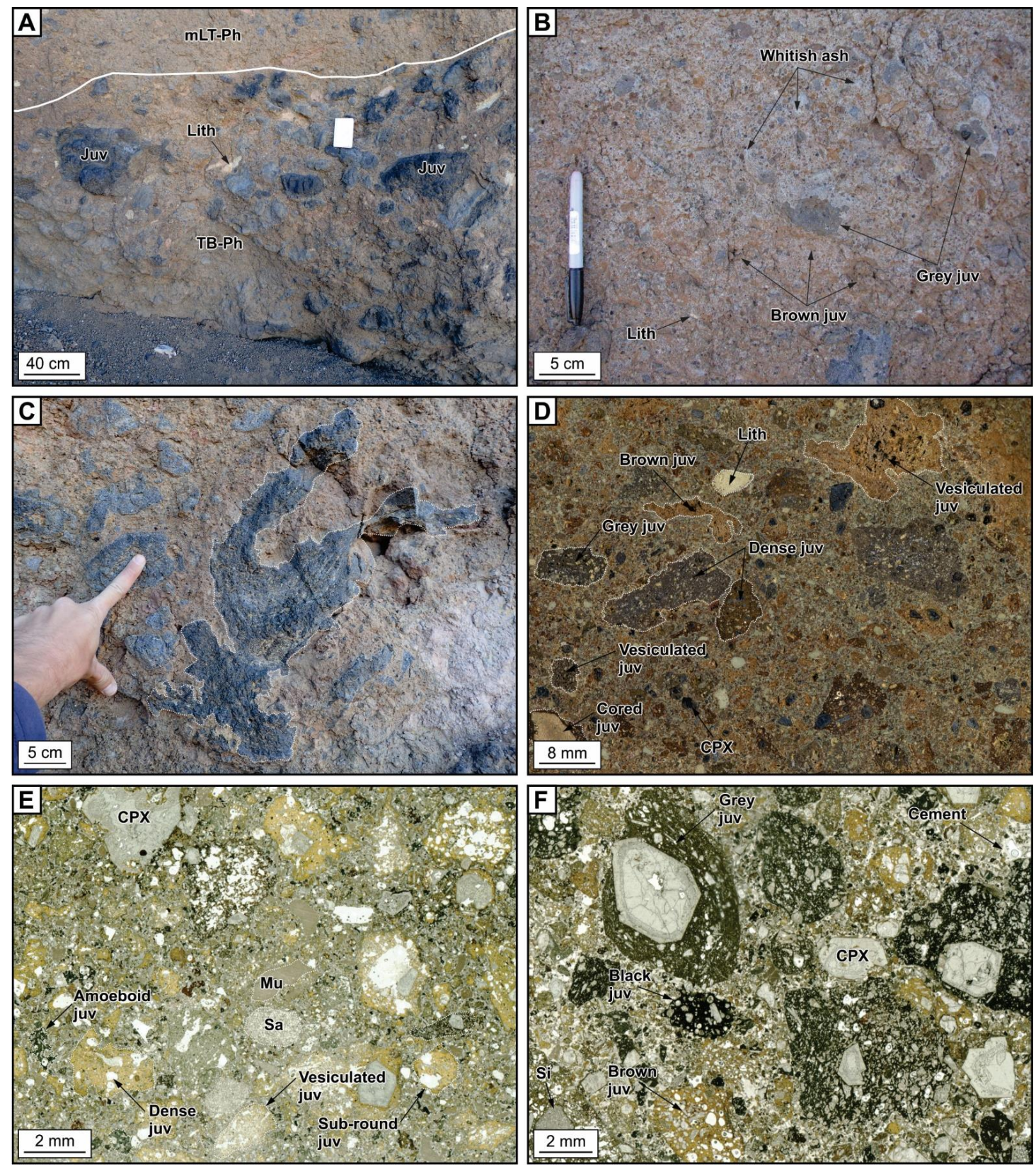

Fig. 7 Photo plate of unit 1. A) TB-Ph bed overlain by a mLT-Ph bed, B) Close-up of the facies mLT$\mathrm{Ph}$ rich in brown juvenile clasts, C) Amoeboid juvenile bomb, D) Slab of the facies mLT-Ph tuff (sample TPN-04 on Fig. 3a), E) High resolution scan of the mLT-Ph facies (sample TPN-04 on Fig. 3a) and F) High resolution scan of the mLT-Ph facies of the South Peak (sample TPS-07 on Fig. 3b). Juv = juvenile clasts, Dense juv = non-vesicular to incipiently vesicular juvenile clasts, Vesiculated clasts = moderately to highly vesicular clasts, $\mathrm{Lith}=$ lithic clasts, $\mathrm{CPX}=$ free clinopyroxene, $\mathrm{Mu}=$ mudstone clasts, $\mathrm{Si}=$ siltstone clasts and $\mathrm{Sa}=$ sandstone clasts. 

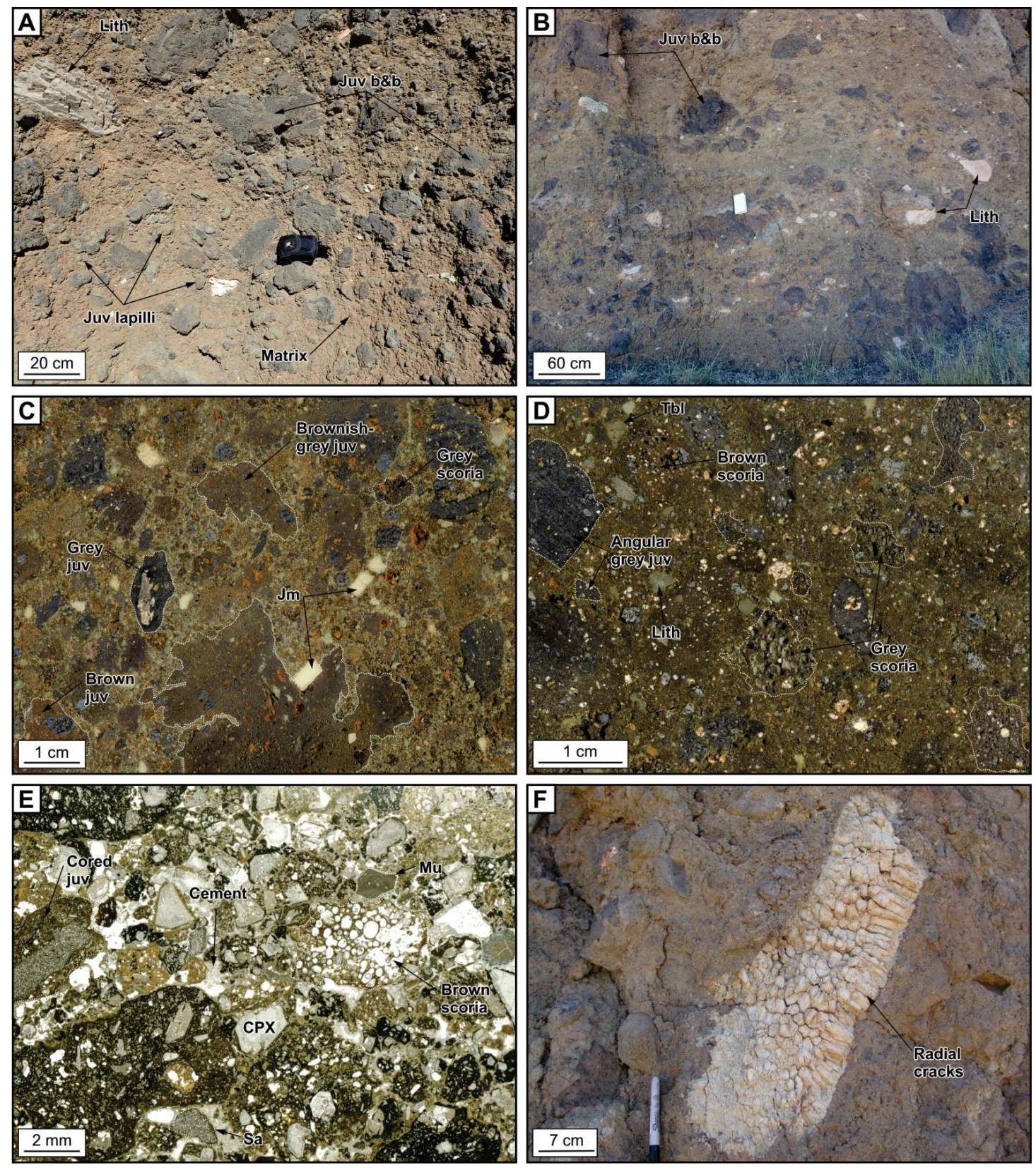

Fig. 8 Photo plate of unit 2. A) Thick bed of TB-S facies on the North Peak, B) Bedded part displaying a lithic-rich TB-S facies at the bottom overlain by beds of mLT-S and TB-S rich in juvenile fragments on the South Peak, C) Slab of the lithic-rich TB-S facies of the North Peak (sample TPN-05 on Fig. 3a), D) Slab of the facies TB-S facies of the South Peak (sample TPS-04 on Fig. 3b), E) High resolution scan of the TB-S facies (sample TPN-15 on Fig. 3a) and F) Cooked Bidahochi block displaying radial cracks. Juv = juvenile clasts, Scoria $=$ moderately to highly vesicular clasts, Lith $=$ lithic clasts, $b \& b=$ blocks and bombs, $\mathrm{CPX}=$ free clinopyroxene, $\mathrm{Tbl}=$ Bidahochi Fm clast, $\mathrm{Jm}=$ Moenave Fm clast, $\mathrm{Mu}=$ mudstone clasts, $\mathrm{Si}=$ siltstone clasts and $\mathrm{Sa}=$ sandstone clasts. 

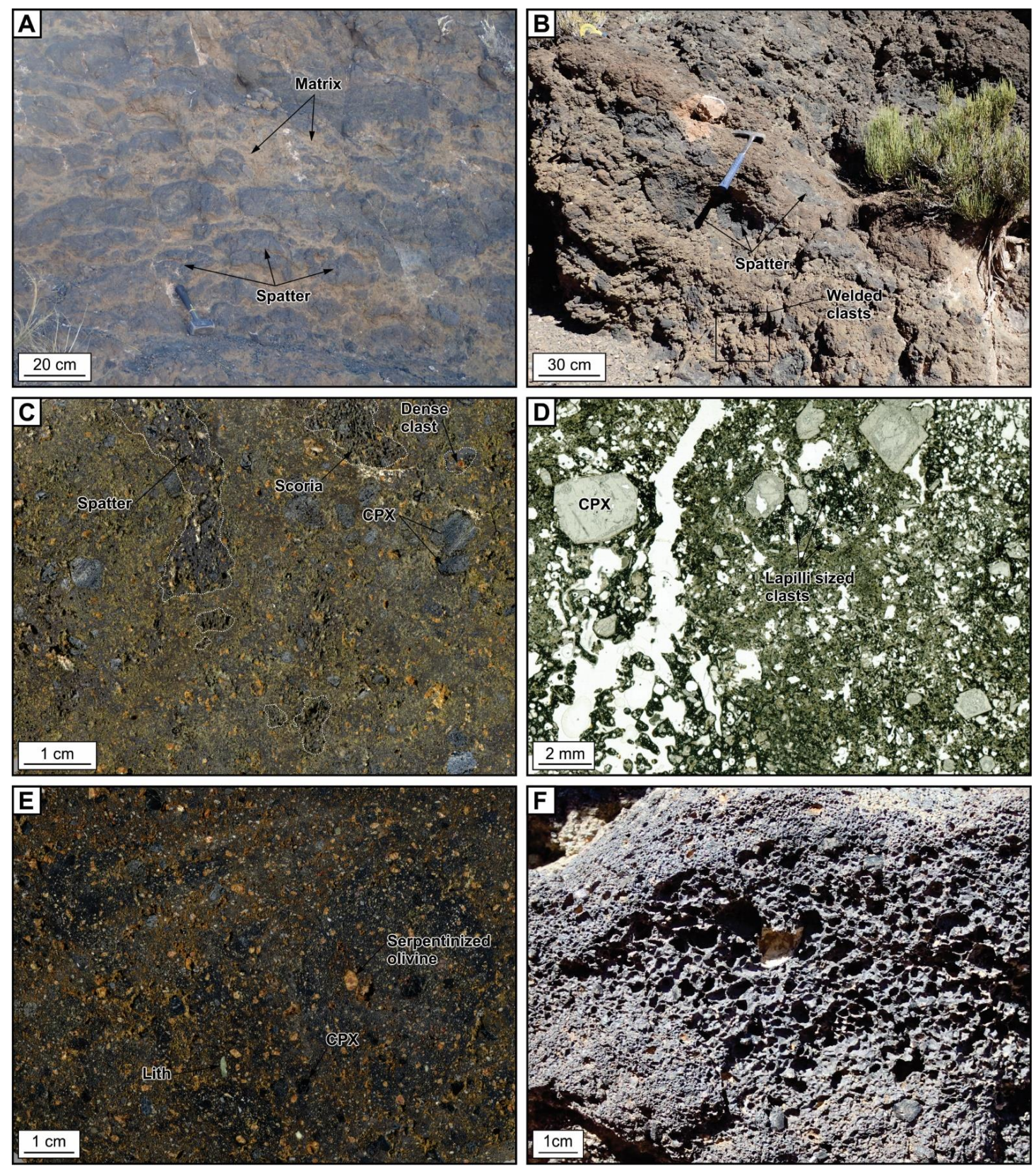

Fig. 9 Photo plate of unit 3. A) Non-welded spatter deposit rich in matrix, B) Welded spatter deposits without matrix, C) Slab of a welded spatter deposit displaying various fragments (sample TPN-14 on Fig. 3a), D) High resolution scan of a welded spatter deposit (sample TPN-14 on Fig. 3a), E) Slab of a lens of a clastogenic lava displaying an homogeneous aspect and F) Spatter bomb with small vesicles at the edge and large vesicles in the center. Lith = lithic clasts, CPX = free clinopyroxene. 

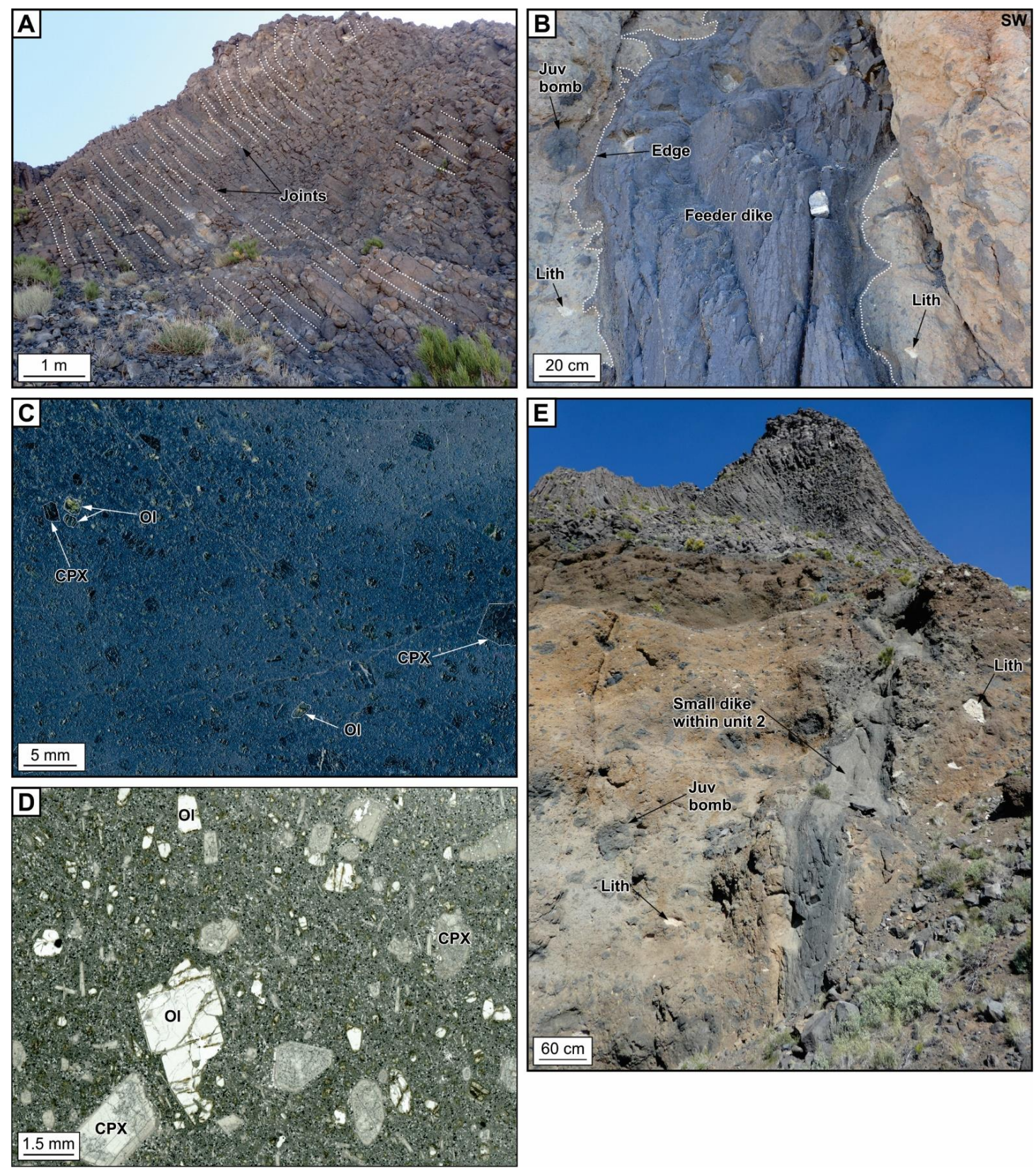

Fig. 10 Photo plate of unit 4. A) Joints within unit 4 of the North Peak, B) Feeder dike displaying amoeboid edges, on the north cliff of the North Peak (Fig. 4), C) Slab of the lava that composes the feeder dike of the North Peak (sample TPN-02 on Fig. 3a), D) High resolution scan of the lava that composes unit 4 (sample TPS-02 on Fig. 3b), E) Small dike with amoeboid edges within unit 2. Juv = juvenile clasts, Dense juv = non-vesicular to incipiently vesicular juvenile clasts, Scoria = moderately to highly vesicular clasts, $\mathrm{Lith}=$ lithic clasts, $\mathrm{CPX}=$ clinopyroxene, $\mathrm{Ol}=$ olivine. 

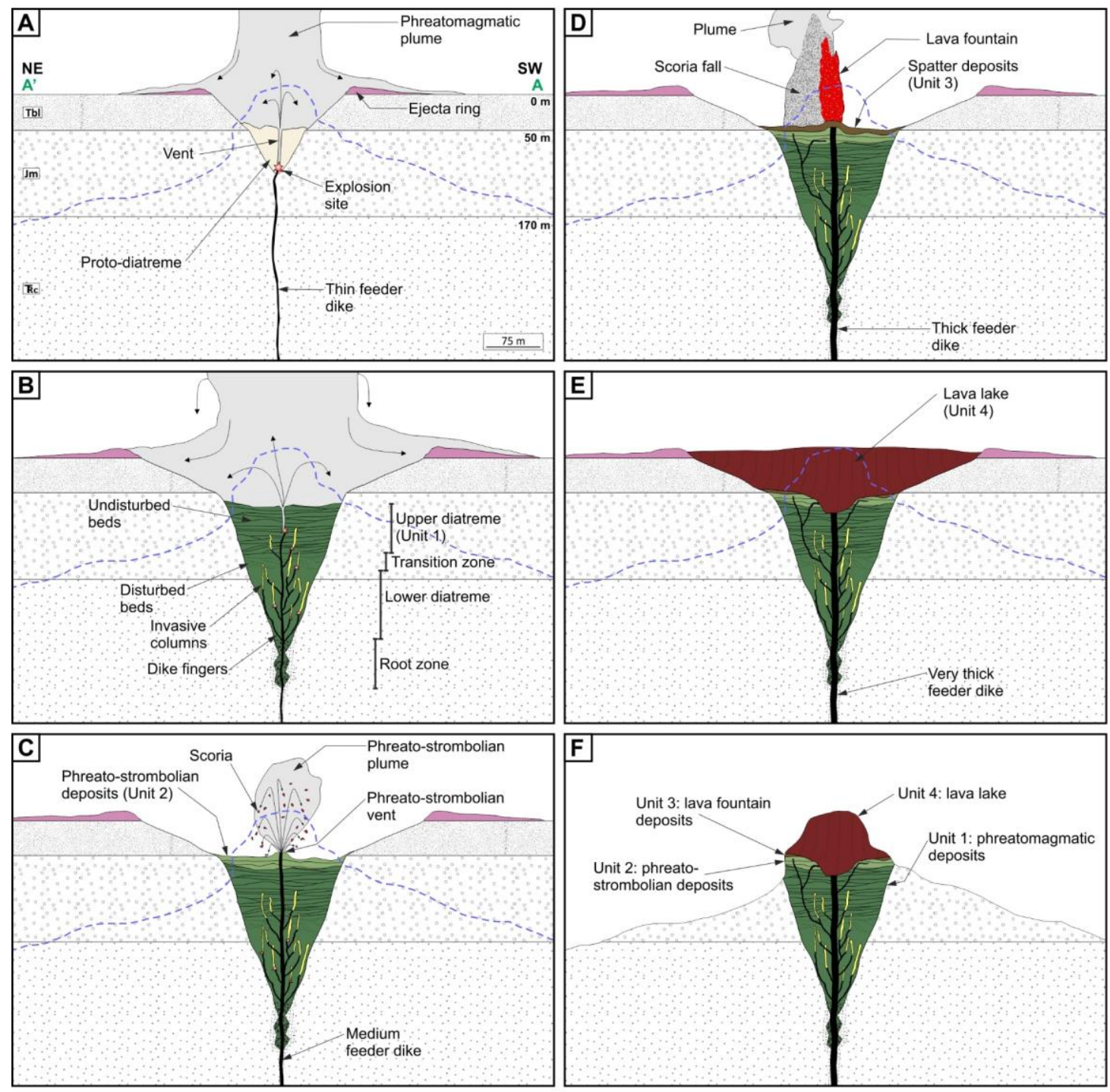

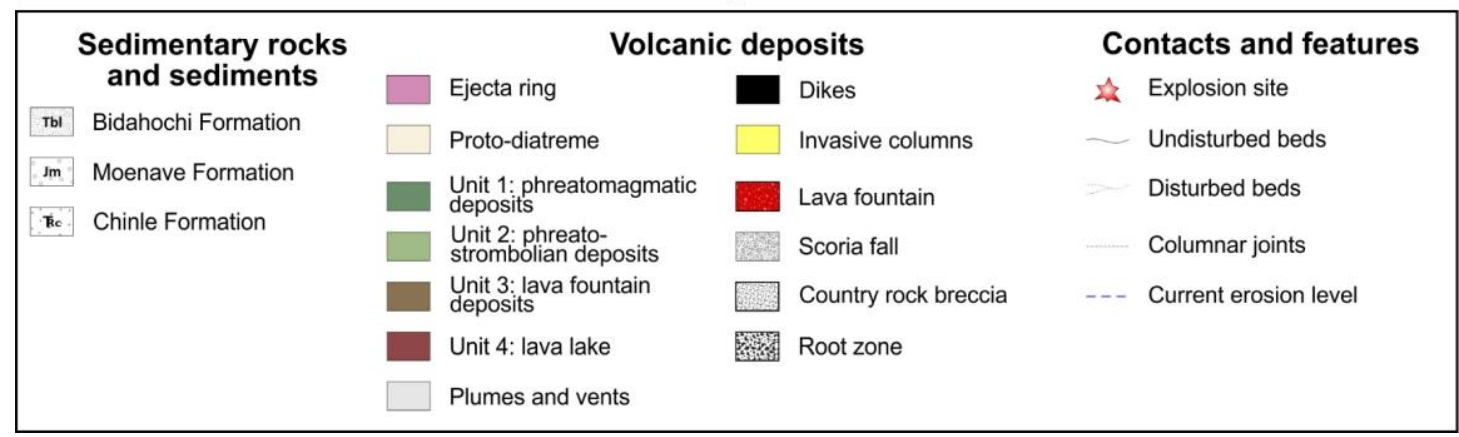

Fig. 11 Twin Peaks evolution model built for the A-A' cross-section in the North Peak (Fig. 2). A) Onset of activity with the first crater and a small proto-diatreme, B) Phreatomagmatic phase building a relatively deep crater and a well-developed diatreme. The upper diatreme/unit 1 crops out at Twin Peaks whereas the transition zone, the lower diatreme with invasive columns and the root zone were not directly observed. These parts of the diatreme are drawn following the model of Latutrie and Ross (2019), C) Phreato-strombolian phase that formed deposits of unit 2, D) Lava fountain phase that formed spatter deposits of unit 3, E) Lava lake filling the crater, F) Current morphology of the North Peak after erosion of the surrounding country rocks. Note: events between step A and step B are unknown, hence the marked difference in the maturity of the diatreme. 

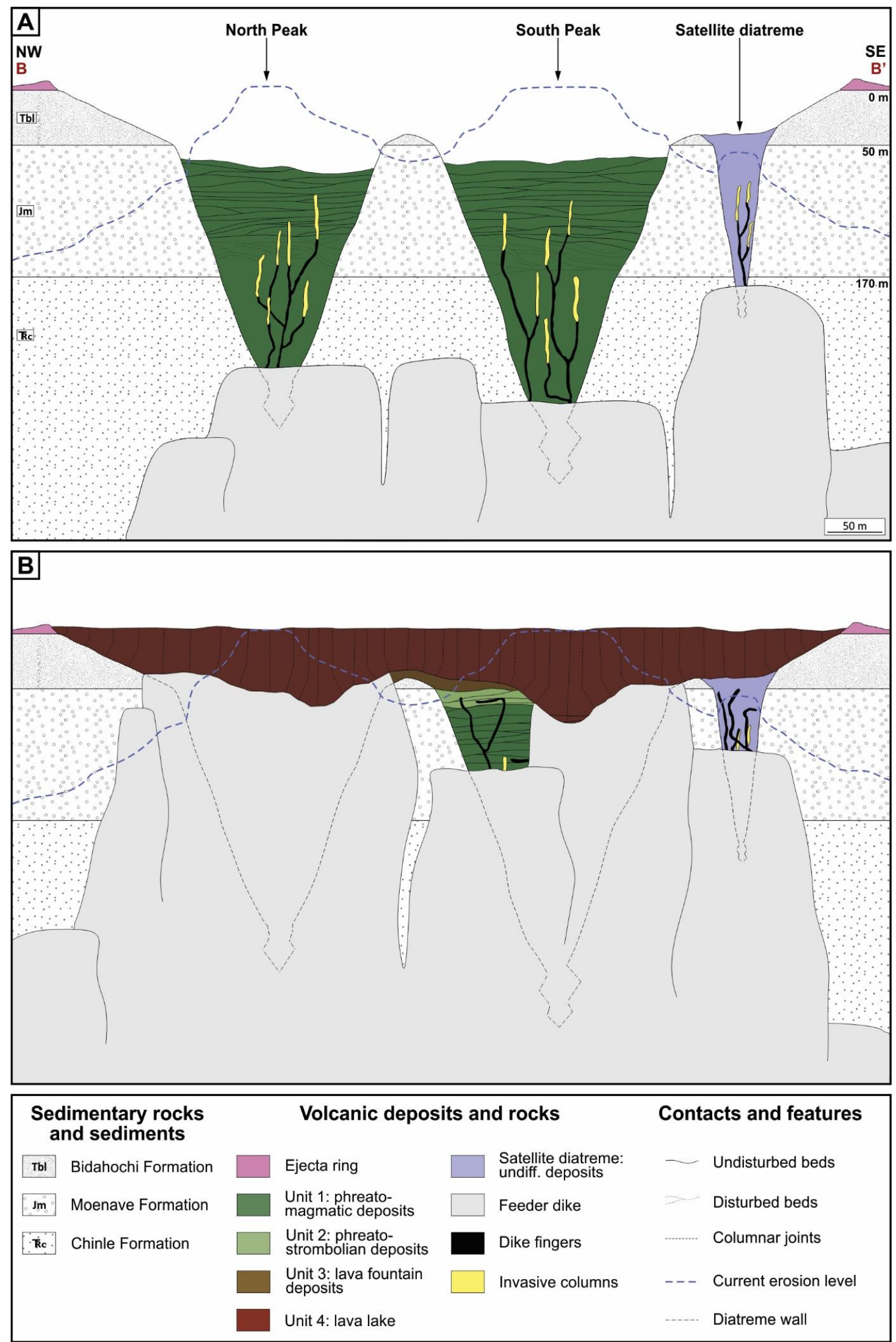

Fig. 12 Longitudinal cross-section of the Twin Peaks volcanic complex parallel to the feeder dike orientation (B-B' in Fig. 2). A) Subterranean morphologies of the North, the South and the satellite diatremes at the end of the emplacement of unit 1, B) Subterranean morphologies of the volcanic complex at the end of the formation of unit 4 . 
Table 1 Results of field clast counts, expressed as percentages of clasts larger than, or equal to, $4 \mathrm{~mm}$

\begin{tabular}{|c|c|c|c|c|c|c|c|c|c|c|c|c|c|}
\hline \multirow[b]{2}{*}{ 苛 } & \multirow[b]{2}{*}{ 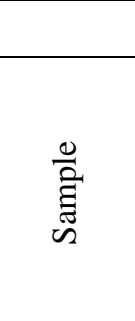 } & \multirow[b]{2}{*}{ 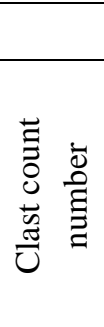 } & \multirow[b]{2}{*}{ 葛 } & \multicolumn{5}{|c|}{ Juvenile clasts } & \multicolumn{4}{|c|}{ Lithic clasts } & \multirow[b]{2}{*}{ 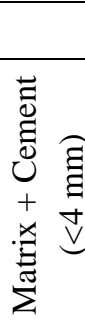 } \\
\hline & & & & 仓े & $\frac{\frac{y}{\tilde{J}}}{\bar{n}}$ & 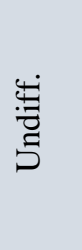 & 总 & స్త్ర & 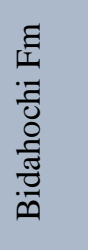 & 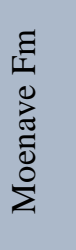 & 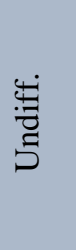 & 胥 & \\
\hline \multicolumn{14}{|c|}{ South peak } \\
\hline 2 & TPS-04 & 2 & 0.0 & 38.0 & 2.0 & 22.0 & 0.0 & 62.0 & 0.0 & 0.0 & 1.0 & 1.0 & 37.0 \\
\hline 2 & TPS-06 & 1 & 0.0 & 56.1 & 1.0 & 0.0 & 0.0 & 57.1 & 0.0 & 0.0 & 0.0 & 0.0 & 42.9 \\
\hline Mean & - & - & 0.0 & 47.1 & 1.5 & 11.0 & 0.0 & 59.6 & 0.0 & 0.0 & 0.5 & 0.5 & 39.9 \\
\hline \multicolumn{14}{|c|}{ North peak } \\
\hline 1 & TPN-07 & 2 & 0.0 & 34.8 & 0.0 & 0.0 & 1.1 & 35.9 & 1.1 & 2.2 & 0.0 & 3.3 & 60.9 \\
\hline 1 & TPN-08 & 3 & 22.2 & 38.4 & 3.0 & 0.0 & 0.0 & 63.6 & 0.0 & 0.0 & 1.0 & 1.0 & 35.4 \\
\hline 1 & TPN-13 & 4 & 6.0 & 25.0 & 6.0 & 5.0 & 2.0 & 44.0 & 0.0 & 0.0 & 14.0 & 14.0 & 42.0 \\
\hline Mean & - & - & 9.4 & 32.7 & 3.0 & 1.7 & 1.0 & 47.8 & 0.4 & 0.7 & 5.0 & 6.1 & 46.1 \\
\hline 2 & TPN-05 & 1 & 0.0 & 46.4 & 0.0 & 19.6 & 0.0 & 66.0 & 0.0 & 0.0 & 1.0 & 1.0 & 33.0 \\
\hline 2 & TPN-15 & 5 & 12.5 & 52.1 & 2.1 & 3.1 & 0.0 & 69.8 & 0.0 & 0.0 & 4.2 & 4.2 & 26.0 \\
\hline Mean & - & - & 6.3 & 49.2 & 1.0 & 11.4 & 0.0 & 67.9 & 0.0 & 0.0 & 2.6 & 2.6 & 29.5 \\
\hline
\end{tabular}


Table 2 Results of petrographic point counts, expressed as a modal percentages

\begin{tabular}{|c|c|c|c|c|c|c|c|c|c|c|c|c|c|c|c|c|c|c|c|c|c|c|c|c|c|c|c|}
\hline \multirow[b]{2}{*}{ 泀 } & \multirow[b]{2}{*}{ 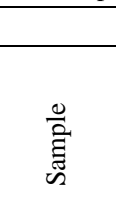 } & \multicolumn{19}{|c|}{ Juvenile clasts } & \multicolumn{5}{|c|}{ Lithic clasts } & \multirow[b]{2}{*}{ 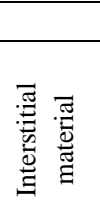 } & \multirow[b]{2}{*}{ U⿺辶寸 } \\
\hline & & & & 总 & & & & & હें & & & & & $\frac{\frac{u}{0}}{\frac{\pi}{n}}$ & & & $\begin{array}{l}5 \\
\overline{0} \\
5\end{array}$ & 己̊ & 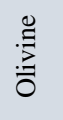 & & $\begin{array}{l}\text { 壳 } \\
\text { ప }\end{array}$ & 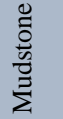 & 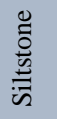 & 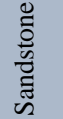 & & & \\
\hline \multicolumn{2}{|c|}{ Vesicularity* (\%) } & ণิ & $\begin{array}{l}\text { + } \\
\text { ?े }\end{array}$ & $\begin{array}{l}8 \\
0 \\
\dot{1}\end{array}$ & $\begin{array}{l}0 \\
\infty \\
0 \\
0 \\
0\end{array}$ & 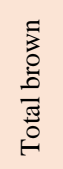 & ণ্ત & $\begin{array}{l}\text { Pे } \\
\text { ?े }\end{array}$ & $\begin{array}{l}8 \\
0 \\
\text { o }\end{array}$ & $\begin{array}{l}0 \\
\infty \\
\vdots \\
0 \\
0\end{array}$ & 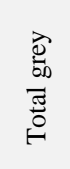 & ণ̊ & $\begin{array}{l}\stackrel{0}{1} \\
\stackrel{i}{1}\end{array}$ & $\begin{array}{l}8 \\
0 \\
\dot{1} \\
+\end{array}$ & $\begin{array}{l}0 \\
\infty \\
0 \\
0 \\
0\end{array}$ & $\begin{array}{l}\frac{y}{0} \\
\frac{\pi}{0} \\
\frac{\pi}{0} \\
\qquad\end{array}$ & - & - & - & 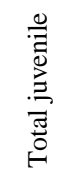 & - & - & - & - & 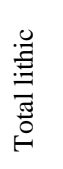 & - & - \\
\hline \multicolumn{28}{|c|}{ South peak } \\
\hline 2 & TPS-04 & 6.2 & 6.5 & 4.2 & 0.0 & 16.9 & 10.2 & 14.6 & 13.2 & 1.2 & 39.0 & 1.9 & 0.9 & 0.0 & 0.0 & 2.8 & 2.1 & 4.9 & 0.2 & 65.8 & 0.0 & 3.5 & 0.2 & 0.0 & 3.7 & 28.9 & 1.6 \\
\hline 2 & TPS-06 & 11.7 & 2.8 & 11.0 & 0.0 & 25.5 & 14.5 & 6.9 & 11.2 & 9.2 & 41.7 & 0.7 & 0.2 & 0.0 & 0.0 & 0.9 & 1.4 & 4.4 & 0.0 & 73.9 & 0.0 & 0.7 & 0.9 & 0.0 & 1.6 & 22.7 & 1.8 \\
\hline Mean & - & 9.0 & 4.6 & 7.6 & 0.0 & 21.2 & 12.3 & 10.7 & 12.2 & 5.2 & 40.4 & 1.3 & 0.6 & 0.0 & 0.0 & 1.8 & 1.7 & 4.6 & 0.1 & 69.8 & 0.0 & 2.1 & 0.6 & 0.0 & 2.7 & 25.8 & 1.7 \\
\hline 1 & TPS-07 & 15.3 & 5.0 & 4.1 & 2.1 & 26.6 & 14.4 & 5.3 & 14.6 & 4.1 & 38.4 & 1.8 & 2.8 & 0.0 & 0.0 & 4.6 & 3.4 & 1.8 & 0.0 & 74.8 & 0.0 & 0.5 & 0.2 & 1.8 & 2.5 & 16.9 & 5.7 \\
\hline \multicolumn{28}{|c|}{ North peak } \\
\hline 1 & TPN-04 & 23.9 & 9.3 & 5.7 & 0.9 & 39.7 & 6.8 & 4.7 & 5.0 & 0.0 & 16.5 & 0.5 & 0.0 & 0.0 & 0.0 & 0.5 & 2.0 & 1.4 & 0.0 & 60.1 & 1.6 & 3.4 & 0.9 & 1.1 & 7.0 & 33.0 & 0.0 \\
\hline 1 & TPN-07 & 4.4 & 0.2 & 0.0 & 0.0 & 4.7 & 9.1 & 12.9 & 5.8 & 8.0 & 35.8 & 0.9 & 0.0 & 0.0 & 0.0 & 0.9 & 2.2 & 4.9 & 3.1 & 51.6 & 4.9 & 1.8 & 0.7 & 0.7 & 8.0 & 40.4 & 0.0 \\
\hline 1 & TPN-13 & 21.2 & 5.7 & 8.2 & 3.2 & 38.3 & 7.8 & 1.1 & 0.5 & 0.9 & 10.3 & 1.4 & 0.0 & 0.0 & 0.0 & 1.4 & 1.4 & 1.1 & 0.2 & 52.6 & 0.7 & 5.2 & 0.2 & 0.5 & 6.6 & 40.8 & 0.0 \\
\hline Mean & - & 16.5 & 5.1 & 4.6 & 1.4 & 27.6 & 7.9 & 6.3 & 3.7 & 3.0 & 20.8 & 0.9 & 0.0 & 0.0 & 0.0 & 0.9 & 1.9 & 2.5 & 1.1 & 54.7 & 2.4 & 3.5 & 0.6 & 0.8 & 7.2 & 38.1 & 0.0 \\
\hline 2 & TPN-05 & 9.6 & 3.1 & 2.9 & 1.4 & 17.1 & 8.7 & 2.7 & 13.3 & 4.3 & 28.9 & 11.8 & 0.2 & 0.2 & 0.0 & 12.3 & 3.6 & 3.9 & 0.2 & 66.0 & 0.0 & 4.6 & 3.1 & 1.4 & 9.2 & 24.8 & 0.0 \\
\hline 2 & TPN-15 & 6.5 & 3.0 & 5.8 & 1.6 & 17.1 & 7.2 & 4.9 & 19.6 & 0.5 & 32.2 & 12.2 & 3.7 & 0.9 & 0.0 & 16.8 & 4.9 & 2.1 & 1.4 & 74.5 & 0.0 & 1.2 & 0.0 & 0.0 & 1.2 & 18.5 & 5.8 \\
\hline Mean & - & 8.1 & 3.1 & 4.4 & 1.5 & 17.1 & 8.0 & 3.8 & 16.4 & 2.4 & 30.6 & 12.0 & 2.0 & 0.6 & 0.0 & 14.6 & 4.3 & 3.0 & 0.8 & 70.3 & 0.0 & 2.9 & 1.6 & 0.7 & 5.2 & 21.6 & 2.9 \\
\hline
\end{tabular}


Table 3 Integration of point counts measurements in clast counts data to calculate the whole componentry of unit 1 and unit 2

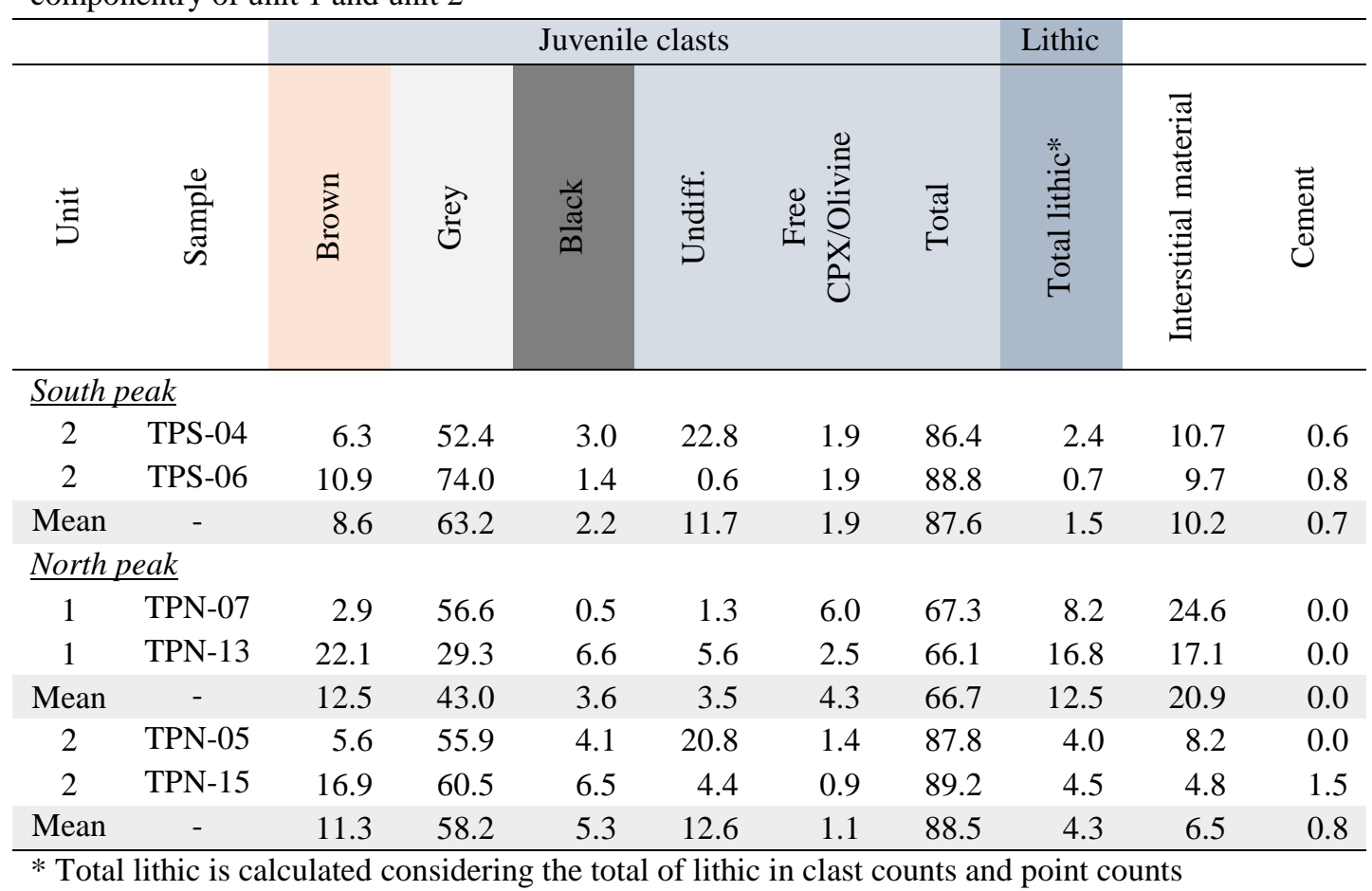


Table 4 Traditional criteria used to distinguish phreatomagmatic from magmatic eruptive styles in basaltic maar-diatreme volcanoes

\begin{tabular}{|c|c|c|c|c|}
\hline $\begin{array}{l}\text { Eruptive style } \\
\text { Maar-diatreme part }\end{array}$ & $\begin{array}{l}\text { Phreatomagmatic } \\
\text { Upper diatreme }\end{array}$ & $\begin{array}{l}\text { Phreatomagmatic } \\
\text { Ejecta ring }\end{array}$ & $\begin{array}{c}\text { Strombolian } \\
\text { Upper diatreme/ejecta ring }\end{array}$ & $\begin{array}{c}\text { Hawaiian } \\
\text { Upper diatreme/ejecta ring }\end{array}$ \\
\hline \multicolumn{5}{|l|}{ Deposits } \\
\hline$\overline{\text { Color }}$ & Paler $^{1}$ & Paler $^{1}$ & Darker $^{1}$ & Darker\# $^{1}$ \\
\hline Thickness of beds & Millimeters to meters $* 2,3,4,5$ & Millimetres to meters $^{2}, 6,7,8,9,10,11,12,13$ & Tens of centimeters to meters ${ }^{\wedge} 10,13,14,15$ & Meters when bedded\# $1,10,13$ \\
\hline Morphology of beds & Sheets to lenses $* \wedge 2,3,4,5$ & Sheets to lenses $2,6,7,8,9,10,11,12,13$ & Sheets draping topography ${ }^{10,13,14,15}$ & Form ramparts ${ }^{1,10,13}$ \\
\hline Structures & $\begin{array}{l}\text { Mostly plane-parallel bedding; rare } \\
\text { crossbedding, dunes or bomb sags }{ }^{2,3,4,5}\end{array}$ & $\begin{array}{l}\text { Mostly plane-parallel bedding; common } \\
\text { crossbedding, dunes and bomb sags }{ }^{2,6,7,8} \\
9,10,11,12,13\end{array}$ & $\begin{array}{l}\text { Internally structureless to diffusely } \\
\text { stratified beds }^{\wedge} 10,13,14,15\end{array}$ & Internally structureless $\# 10,13$ \\
\hline Mode of emplacement & PDCs, fallback $* \wedge$, ballistic bombs ${ }^{2,3,4,5}$ & $\begin{array}{l}\text { PDCs, mostly surges (rare pyroclastic } \\
\text { flows), fallout, ballistic bombs } 2,6,7,8,9,10 \text {, } \\
11,12,13\end{array}$ & $\begin{array}{l}\text { Fallout from plume }{ }^{\wedge} \text {, ballistic bombs }{ }^{10,13} \\
14,15\end{array}$ & $\begin{array}{l}\text { Fallout from fountain\#, ballistic bombs }{ }^{10} \text {, } \\
13\end{array}$ \\
\hline Degree of sorting & Generally poorly sorted $* \wedge 2,3,4,5$ & Variably sorted $2,9,10,11,12,13$ & $\begin{array}{l}\text { Better sorted than phreatomagmatic } \\
\text { deposits }^{\wedge} 10,13,14,15\end{array}$ & $\begin{array}{l}\text { Better sorted than phreatomagmatic } \\
\text { deposits\# } 10,13 \text {, }\end{array}$ \\
\hline Fine particle content & High ash content $* \wedge 2,3,4,5,16$ & High ash content ${ }^{2}, 10,11,12,13,16$ & $\begin{array}{l}\text { Low ash content in proximal deposits }{ }^{10,13} \text {, } \\
14,15,17,18\end{array}$ & $\begin{array}{l}\text { Low ash content in proximal deposits\# }{ }^{10} \text {, } \\
13\end{array}$ \\
\hline Size of particles & $\begin{array}{l}\text { Extremely fine ash }(<63 \mu \mathrm{m}) \text { to blocks } \\
\text { and bombs }(>64 \mathrm{~mm}) * \wedge 3,4,5\end{array}$ & $\begin{array}{l}\text { Extremely fine ash }(<63 \mu \mathrm{m}) \text { to blocks } \\
\text { and bombs }(>64 \mathrm{~mm})^{2}, 10,11,12,13,16\end{array}$ & $\begin{array}{l}\text { Fine lapilli ( }>2 \mathrm{~mm} \text { ) to blocks and bombs } \\
(>64 \mathrm{~mm}) \text { in proximal deposits }{ }^{15,17,18}\end{array}$ & $\begin{array}{l}\text { Coarse lapilli (>2 mm) to blocks and } \\
\text { bombs (>64 mm) in proximal deposits\# }{ }^{10} \text {, } \\
13\end{array}$ \\
\hline Lithic content & $\begin{array}{l}\text { Low to high (few tens of } \% \text { to over } 80 \% \text { )* } \\
1,2,3,4,5,19\end{array}$ & $\begin{array}{l}\text { Low to very high (few } \% \text { to } 90 \%)^{1,2,10,11 \text {, }} \\
12,13,19,20\end{array}$ & Nil to low $(5 \%)^{\wedge} 1,10,13,14,15,18,21$ & Nil to low $(5 \%) \#^{1,10,13,21}$ \\
\hline Accretionary lapilli & Possible but often absent ${ }^{1,21}$ & Possible but often absent ${ }^{1,8,21,22}$ & $\mathrm{No}^{1,21}$ & No\# 1,21 \\
\hline Cementation & Typically cemented $* \wedge 1,2,3,4,5$ & Poorly to strongly cemented ${ }^{1,10,11,12,13}$ & Usually poorly cemented ${ }^{10,13,14,15}$ & Non to poorly cemented\# 10,13 \\
\hline $\begin{array}{l}\text { Agglutination/welding } \\
\text { Juvenile clasts }\end{array}$ & $\mathrm{No}^{* \wedge} 1,3,21$ & $\mathrm{No}^{1,10,12,13}$ & Possible $^{1,15,18}$ & Non to strongly welded\# $1,23,24$ \\
\hline$\overline{\text { Vesicularity }}$ & $\begin{array}{l}\text { Typically non to moderately vesicular; } \\
\text { rarely highly vesicular* } \wedge 1,21,25\end{array}$ & $\begin{array}{l}\text { Typically non to moderately vesicular; } \\
\text { rarely highly vesicular } 1,10,21,25\end{array}$ & $\begin{array}{l}\text { Moderately to extremely vesicular^ }{ }^{\wedge} 1,14,15 \text {, } \\
\text {, }\end{array}$ & Moderately to extremely vesicular ${ }^{1,24,25,26}$ \\
\hline Size of vesicles & Typically small $* \wedge 1,21,25$ & Typically small ${ }^{1,10,21,25}$ & Can be large and coalesced ${ }^{\wedge} 1,18,25$ & Can be large and coalesced\# $1,18,25,26$ \\
\hline Morphology/shape & $\begin{array}{l}\text { Angular/blocky to irregular/amoeboid } * \wedge \\
21,27,28,29\end{array}$ & $\begin{array}{l}\text { Angular/blocky to irregular/amoeboid }{ }^{21,27,} \\
28,29\end{array}$ & $\begin{array}{l}\text { Mainly scoria^ }{ }^{\wedge} \text {, shape is controlled by } \\
\text { vesicles }^{\wedge} 18,24,29\end{array}$ & $\begin{array}{l}\text { Mainly scoria/spatter\#, shape is controlled } \\
\text { by vesicles\# } 18,24,26,29\end{array}$ \\
\hline Loaded/cored bombs & Frequent ${ }^{11,30}$ & Frequent ${ }^{11,30}$ & Rare & Absent \\
\hline
\end{tabular}

*Criteria found in unit 1 at Twin Peaks, ^ Criteria found in unit 2 at Twin Peaks, \# Criteria mainly found in unit $3 b$ at Twin Peaks 


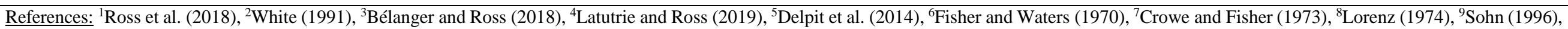

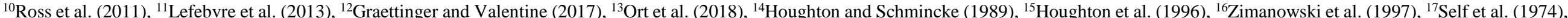

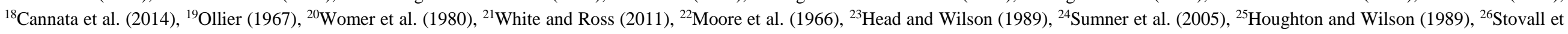

al. (2012), ${ }^{27}$ Walker and Croasdale (1971), ${ }^{28}$ Heiken (1972), ${ }^{29}$ Heiken and Wohletz (1985), ${ }^{30}$ Sottili et al. (2010) 